Western University

Scholarship@Western

Department of Economics Research Reports

Economics Working Papers Archive

1979

\title{
The Size and Structure of Union-Nonunion Wage Differentials in Canadian Industry
}

Glenn M. MacDonald

John C. Evans

Follow this and additional works at: https://ir.lib.uwo.ca/economicsresrpt

Part of the Economics Commons

Citation of this paper:

MacDonald, Glenn M., John C. Evans. "The Size and Structure of Union-Nonunion Wage Differentials in Canadian Industry."

Department of Economics Research Reports, 7925. London, ON: Department of Economics, University of Western Ontario (1979). 
ISSN : $\quad 0318-725 \mathrm{X}$

ISBN :

RESEARCH REPORT 7925

THE SIZE AND STRUCTURE OF UNION-NONUNION WAGE DIFFERENTIALS IN CANADIAN INDUSTRY

$$
\text { by }
$$

Glenn M. MacDonald and

John C. Evans

August, 1979 
THE SIZE AND STRUCTURE OF UNION-NONUNION

\title{
WAGE DIFFERENTIALS IN CANADIAN INDUSTRY
}

\author{
Glenn M. MacDonald*
}

and

\author{
John C. Evans *
}

August 1979

* Glenn M. MacDonald is Assistant Professor of Economics at the University of Western Ontario, London, Ontario. John C. Evans is Associate Professor of Economics at York University, Downsview, Ontario. 
The Size and Structure of Union-Nonunion Wage Differentials

in Canadian Industry ${ }^{\dagger}$

\section{INTRODUCTION}

The size of the union-nonunion wage differential in the United States has been the subject of considerable study and debate. Few empirical studies have been conducted using Canadian data. ${ }^{1}$ In this paper we estimate unionnonunion wage differentials for three skill groups using pooled time-series and cross-section data for 57 Canadian industries. This sample is large enough to provide the degrees of freedom required to generate efficient estimates at the industry level.

There are a number of interesting findings. First, we employ a test devised by Hausman [4] to determine that union coverage should be treated as endogenous variable in wage equations.

Second, utilizing an error components model, we find that even after taking account of a number of factors, there are substantial unmeasured permanent industry-8pecific differences in $10 \mathrm{~g}$ wages. These permanent effects comprise $42 \%$ of the unexplained variation in $10 \mathrm{~g}$ wage rates.

Third, the hypotheses that union-nonunion wage differentials are constant across industries, or across skill groups, or both are all rejected. Consequently, estimates based on the assumption of a constant differential are very likely misspecified. Our estimates indicate that this specification error may lead to a $20 \%$ understatement of the average differential.

Fourth, evidence is provided on the structure of wage differentials by skill group. The average differentials are $19.8 \%$ for skilled workers, $18.5 \%$ for semi-skilled workers, and $21.7 \%$ for the unskilled. ${ }^{2}$ The most novel result is that increasing the fraction of female employees substantially raises the differentials for all skill groups. 


\section{Wage Rates and Union Coverage}

In this section we derive an equation relating industry average wages to observable magnitudes..$^{3}$ Estimation of the equation yields information on the union-nonunion wage differential by skill group.

Consider a single industry comprised of identical firms. Let there be S skill groups. In each skill group only some of the workers will be unionized. Assume that within each of the 2S skill-unionization groups all workers are identical.

Equilibrium in the labor market results in a wage function that depends on the characteristics of the worker-firm match. Let characteristics of the firm be $Y$. Workers characteristics are $X_{s}^{u}$ and $X_{s}^{n}$ where $s(s=1, \ldots, s)$ indexes skill groups and $u$ and $n$ index union status $(u=$ union and $n=$ nonunion).- Define the variable $D_{u}=1$ if the group is unionized, and $D_{u}=0$ otherwise. The wage function is $w=f\left(X, Y, D_{u}\right)$ yielding

$$
w_{s}^{u}=f\left(X_{s}^{u}, Y, 1\right) \quad \text { for union workers }
$$

and

$$
w_{s}^{n}=f\left(X_{s}^{n}, Y, 0\right) \quad \text { for nonunion workers. }
$$

Implicit in $f(\cdot)$ are prices for the characteristics $X, Y$ and $D_{u} \cdot$ Assume that $f(\cdot)$ may be represented by

$$
\log w_{s}^{u}=x_{s}^{u_{\beta}}+Y \gamma+\phi_{s}
$$

and

$$
\log w_{s}^{n}=x_{s}^{n} \beta+Y \gamma
$$

$\beta$ and $\gamma$ are vectors of constants (from which the implicit prices of the characteristics may be inferred). For a given set of characteristics, the percentage union-nonunion wage differential $\left(w_{s}^{u}-w_{s}^{n}\right) / w_{s}^{n}$, is measured by $e^{\phi_{s}}-14^{4}$ 
Let $\alpha_{8}$ represent the fraction of workers of skill type $s$ in the industry, and let $u_{s}$ denote the fraction of those workers that are unionized. Then the average $\log$ wage in the industry (the $\log$ of the geometric mean) is

$$
\log \bar{w}=\sum_{s=1}^{S} \alpha_{s}\left[u_{s} \log w_{s}^{u}+\left(1-u_{s}\right) \log w_{s}^{n}\right]
$$

Assume, as the industry data unfortunately require, that $u_{s}=\sum_{s=1}^{s=s} \alpha_{s} u_{s} \equiv u$ for all $s$, where $u$ is the degree of union coverage for the industry. Then (1) and (2) yield

$$
\log \bar{w}=\bar{X} \beta+Y \gamma+u \quad \sum_{s=1}^{S} \alpha_{s} \phi_{s},
$$

where

$\$$

$$
\bar{x}=\sum_{s=1}^{s} \alpha_{s}\left[u_{s} x_{s}^{u}+\left(1-u_{s}\right) x_{s}^{n}\right]
$$

is a vector of industry average worker characteristics.

Indexing industries by $i=1, \ldots, N$, the nonstochastic portion of the equation to be estimated is

$$
\log \bar{w}_{i}=\bar{x}_{i} \beta+Y_{i} \gamma+u_{i} \sum_{s=1}^{s} \alpha_{s_{i}} \phi_{s_{i}}
$$

Cross-industry variation in $\phi_{s}$ is not ruled out a priori. When $\phi_{s}$ is variable, it is parameterized by

$$
\phi_{8}=\mathrm{Z} \delta_{8}
$$

where $Z$ may contain some variables from each of $\bar{X}$ and $Y$ as well as others. In this case the equation to be estimated is

$$
\log \bar{w}_{1}=\bar{X}_{i} \beta+Y_{i} \gamma+u_{i} \sum_{s=1}^{S} \alpha_{s_{i}} Z_{i} \delta_{s} \text {. }
$$

The requisite data are $\bar{w}_{1}, X_{i}, Y_{i}, \alpha_{s_{i}}, u_{i}$ and $Z_{i}$. Parameters to be estimated are $\beta, \gamma$ and $\delta_{8}(s=1, \ldots, s)^{6}$. 


\section{Stochastic Specification of the Wage Equation}

The specific structure of (5) is not important for the present discussion. For notational convenience, therefore, we write (5) in the form

$$
w_{i t}=\Omega_{i t} \varphi
$$

where $w_{1 t}$ is the natural $\log$ of the average wage in industry $i$ at time $t, \Omega_{i t}$ is an appropriately defined regressor matrix and $\varphi^{\prime}$ is the vector $\left(\beta^{\prime}, \gamma^{\prime}, \delta_{1}^{\prime}, \ldots, \delta_{s}^{\prime}\right)$.

The stochastic structure of $(6)$ is assumed to be of the error components type. The present case is somewhat more complicated than the usual for three reasons: the dependent variable is an average, the data are such that the number of observations over time is not constant across industries, 7 and there is the possibility that $u$ is endogenous. Discussion of the endogeneity of $u$ is deferred until the next section.

The equation to be examined is

$$
w_{i t}=\Omega_{i t} \varphi+\beta_{i}+\nu_{t}+\varepsilon_{i t}
$$

where $t=1, \ldots, T_{i}$ and $i=1, \ldots, N$. That $i s$, for industry $i$ there are $T_{i}$ observations on $w_{i}$ and $\Omega_{i} \cdot \mu_{i}$ is an industry-specific disturbance which is fixed over time for a given industry, representing unmeasured factors that make for permanent wage differences across industries. $\nu_{t}$ represents

time-dependent factors which affect all industries equally (in the percentage sense). $\epsilon_{i t}$ is a transitory wage component that varies across industries and over time. 
Given the error specification in (7), it is necessary to decide whether $\mu_{1}$ and $\nu_{t}$ should be treated as parameters that are fixed in repeated samples or as random variables. We shall take $\nu_{t}$ as fixed (estimating $\nu_{t}$ with time dummies) and treat $\mu_{1}$ as random variables. Accordingly, it is assumed that the $\mu_{1}$ and $\varepsilon_{i t}$ are stochastically independent and that

$$
\begin{aligned}
E\left(\mu_{1}\right) & =E\left(\varepsilon_{i t}\right)=0 \quad \forall \quad \begin{array}{l}
t=1, \ldots, T_{i} \\
i=1, \ldots, N
\end{array} \\
E\left(\mu_{i} \mu_{j}\right) & = \begin{cases}\sigma_{\mu_{1 t}}^{2} & i=j \\
0 & \text { otherwise }\end{cases} \\
E\left(\varepsilon_{i t^{8} j t^{\prime}}\right) & = \begin{cases}\sigma_{\epsilon_{i t}}^{2} & i=j, t=t^{\prime} \\
0 & \text { otherwise. }\end{cases}
\end{aligned}
$$

In contrast to the standard case, the variance of the error components may depend on 1 and $t$. This occurs because the data are averaged across firm units, the data from which are presumably averages across individuals. For each $i$ and $t$, let $R_{i t}$ denote the number of reporting units, and $E_{i t}^{j}$ denote employment in reporting unit $j\left(j=1, \ldots, R_{i}\right)$. Total employment in industry 1 at time $t$ is then

$$
\sum_{j=1}^{R_{1 t}} E_{i t}^{j}=R_{i t} \frac{\sum_{j=1}^{R_{i t}} E_{i t}^{j .}}{R_{i t}} \equiv R_{i t} \bar{E}_{i t},
$$

the product of the number of reporting units and average employment per reporting unit $\left(\overline{\mathrm{E}}_{1 t}\right)$. Homoscedasticity at the reporting unit level implies

$$
\sigma_{1 t}^{2}=\sigma_{i}^{2} / R_{1 t}
$$

and $\quad \sigma_{\mu_{1 t}}^{2}=\sigma_{\mu}^{2} / R_{1 t}$

for some $\sigma_{\mu}^{2}, \sigma_{\epsilon}^{2}>0$. On the other hand, homoscedasticity at the individual worker level implies 


$$
\sigma_{e_{1 t}}^{2}=\sigma_{e}^{2} / R_{1 t} \bar{E}_{i t}
$$

and $\quad \sigma_{\mu_{1 t}}^{2}=\sigma_{\mu}^{2} / R_{1 t} \bar{E}_{1 t}$.

We.adopt the flexible specification

$$
\sigma_{\epsilon_{i t}}^{2}=\sigma_{6}^{2} / R_{i t}^{\pi_{1}} \overline{\mathrm{E}}_{i t}^{\pi_{2}}
$$

and $\sigma_{\mu_{i t}}^{2}=\sigma_{\mu}^{2} / R_{i t}^{\pi_{1}} \bar{E}_{i t}^{\pi_{2}}$ where

$\pi_{1}$ and $\pi_{2}$ are to be estimated. It is expected that both $\pi_{1}$ and $\pi_{2}$ are nonnegative. Estimation of $\pi_{1}$ and $\pi_{2}$ requires an initial consistent estimation of (7). This yields consistent estimates of $\mu_{i}+\epsilon_{i t}$, say $\hat{e}_{i t} \cdot \pi_{1}$ and $\pi_{2}$ may then be estimated by computing the ordinary least squares regression

$$
\log \hat{e}_{i t}^{2}=\pi_{0}-\pi_{1} \log R_{i t}-\pi_{1} \log \bar{E}_{i t}
$$

The estimated values, $\hat{\pi}_{1}$ and $\hat{\pi}_{2}$, are used to construct the weighting factor $\Lambda_{i t}=\left[R_{i t}^{\hat{\pi}_{1}} \bar{E}_{i t}^{\hat{\pi}_{2}}\right]^{1 / 2}$. Denoting variables multiplied by $\Lambda_{\text {it }}$ with an asterisk, the homoscedastic model is 8

$$
\begin{aligned}
w_{i t}^{*} & =\Omega_{i t^{\varphi}}^{*}+\nu_{t}^{*}+\eta_{1 t} \\
\eta_{1 t} & =\mu_{i}^{*}+\varepsilon_{i t}^{*} \\
E\left(\eta_{1 t}\right) & =0 \\
E\left(\eta_{i t} \eta_{j t^{\prime}}\right) & = \begin{cases}\sigma_{\mu}^{2}+\sigma_{e}^{2} \\
\sigma_{\mu}^{2} \\
0 & i=j, t=t^{\prime} \\
0 & i \neq j, t \neq t^{\prime}\end{cases}
\end{aligned}
$$

The covariance matrix of $\eta_{i t}$ is non-diagonal. Efficient estimation of (8) therefore entails using generalized least squares. It is stralghtforward to show that generalized least squares is numerically equivalent to the ordinary least squares regression of $\tilde{w}_{i t}$ on $\tilde{\Omega}_{i t}$ where ${ }^{9}$ 


$$
\begin{aligned}
& \tilde{w}_{1 t}=w_{1 t}-\lambda_{1} \tilde{w}_{1} \\
& \widetilde{\Omega}_{1 t}^{k}=\pi_{1 t}^{k}-\lambda_{1} \bar{\Omega}^{k} \\
& \lambda_{1}=1-\left(\frac{\sigma_{6}^{2}}{\sigma_{\epsilon}^{2}+\mathrm{T}_{i} \sigma_{\mu}^{2}}\right)^{1 / 2} \\
& \bar{w}_{1}=\frac{1}{T_{1}} \sum_{t=1}^{T_{1}} w_{i t} \\
& \bar{\Omega}_{1 t}^{k}=\frac{1}{T_{1}} \sum_{t=1}^{T_{1}} \delta_{1 t}^{k}
\end{aligned}
$$

and $\tilde{\Omega}_{i t}^{k}$ is the $k^{\text {th }}$ element of $\tilde{\Omega}_{i t}$. We refer to this procedure as random effects (RE) estimation. When the same procedure is used, but with instrumental variables in place of OLS, we refer to it as random effects-instrumental variables (REIV) estimation.

If this procedure is to be operational, $\lambda_{1}$ (which depends on the unknown $\sigma_{\epsilon}^{2}$ and $\sigma_{\mu}^{2}$ ) must be estimated. Estimation of $\lambda_{1}$ requires consistent estimation of $\sigma_{\epsilon}^{2}$ and $\sigma_{\mu}^{2}$. Following Graybill [3], consistent estimates are provided by

$$
\begin{aligned}
& \hat{\sigma}_{\varepsilon}^{2}=\frac{1}{T-N} \sum_{i=1}^{N} \sum_{t=1}^{T_{i}}\left(\hat{\eta}_{i t}-\hat{\eta}_{i}\right)^{2} . \\
& \hat{\sigma}_{\mu}^{2}=\frac{1}{T_{0}}\left[\frac{1}{N-1} \sum_{i=1}^{N} T_{i}\left(\hat{\eta}_{i}-\hat{\eta}_{.}\right)^{2}-\hat{\sigma}_{\epsilon}^{2}\right]
\end{aligned}
$$

where $\hat{\eta}_{\text {It }}$ is a consistent estimate of $\eta_{i t}$, obtained from an initial consistent estimation of (8), and

$$
\begin{aligned}
& T=\sum_{i=1}^{N} T_{i}=\text { total number of observations; } \\
& \hat{T}_{1 .}=\frac{1}{T_{1}} \sum_{t=1}^{T} \hat{\eta}_{1 t}=\text { average estimated disturbance in industry } i ;
\end{aligned}
$$


and

$$
\begin{aligned}
& \hat{\eta}_{. .}=\frac{1}{T} \sum_{i=1}^{N} \sum_{t=1}^{T_{i}} \hat{T}_{i . t}=\text { average estimated } \\
& T_{0}=\frac{T^{2}-\sum_{i=1}^{N} T_{i}^{2}}{T(N-1)}=\frac{T}{N-1}-\frac{\frac{1}{N} \sum_{i=1}^{N} T_{i}^{2}}{\frac{(N-1)}{N} \sum_{i=1}^{N} T_{i}}
\end{aligned}
$$

$\approx$ average number of observations per industry. 11

The generalized least squares procedure, using $\hat{\sigma}_{\epsilon}^{2}$ and $\hat{\sigma}_{\mu}^{2}$ is asymptotically efficient and yields maximum likelihood estimates (under the assumption that

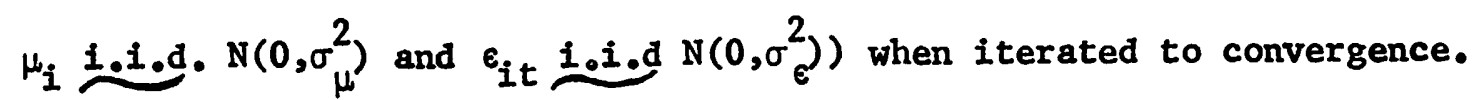

Briefly summarizing, the model is first estimated by a simple consistent technique such as instrumental variables, and $\Lambda_{i t}$ is computed from the residuals. A heteroscedasticity correction (multiplying the data by $\Lambda_{i t}$ ) is made, and the variance components $\sigma_{\epsilon}^{2}$ and $\sigma_{\mu}^{2}$ are then estimated from the residuals of a second consistent estimation using the weighted data. $\lambda_{i}$ is then estimated, and the full generalized least squares estimates produced.

\section{A Test for the Endogeneity of Union Coverage in the Wage Equation}

The degree of union coverage in the industry (u) may be an endogenous variable in (5) for a number of reasons. Suppose, for example, that there is a large union facing an industry comprised of competitive firms. If the union leadership is concerned with both the size of the union and the union wage, then the extent of unionization and one component $\left(w_{s}^{u}\right)$ of industry average wages are choice variables for the union, and $u$ becomes endogenous.

The consequences of endogeneity of $u$ are, of course, serious in terms of the estimation of (8). If either 


$$
E(\mu \mid \Omega) \neq 0
$$

or

$$
E(B \mid \Omega) \neq 0
$$

hold, either of which implies

$$
E(\eta \mid u) \neq 0
$$

the RE estimator of the previous section is inconsistent. 12

The test presented below follows from the following powerful result derived by Hausman [4]. In our notation, let the null hypothesis be

$$
\mathrm{H}_{0}: \quad \mathrm{E}(\eta \mid \mathrm{u})=0,
$$

and let the alternative be

$$
\mathrm{H}_{1}: \mathrm{E}(\eta \mid \mathbf{u}) \neq 0
$$

Suppose there are two estimators of $\varphi: \hat{\varphi}_{0}$, which is consistent and asymptotically efficient only under $H_{0}$, and $\hat{\varphi}_{1}$ which is consistent under both $H_{0}$ and $H_{1}$. Let $V\left(\hat{\varphi}_{0}\right)$ and $V\left(\hat{\varphi}_{1}\right)$ denote consistent estimates of the covariance matrices of $\hat{\varphi}_{0}$ and $\hat{\varphi}_{1}$. Then, under $\mathrm{H}_{0}$, the statistic

$$
T\left(\hat{\varphi}_{1}-\hat{\varphi}_{0}\right)^{\prime}\left[V\left(\hat{\varphi}_{1}\right)-V\left(\hat{\varphi}_{0}\right)\right]^{-1}\left(\hat{\varphi}_{1}-\hat{\varphi}_{0}\right)
$$

is asymptotically distributed as $\chi_{(K)}^{2}$ where $K$ is the number of regressors. Large values of (9) imply correlated regressors and errors. Rejection of $\mathrm{H}_{0}$ implies that $\mathrm{u}$ must be treated as endogenous.

The intuition behind the Hausman test is straightforward. Only under $\mathrm{H}_{0}$ are both estimators consistent. Accordingly, the estimates should be similar; $\left|\hat{\varphi}_{1}-\hat{\varphi}_{0}\right|$ should be small.

Assuming $E(\eta \mid u)=0$, the RE estimator is consistent and asymptotically efficient. The REIV estimator is consistent regardless of $E(\eta \mid u)$. The REIV estimator is computed in the same fashion as the RE estimator, but with $u_{\text {it }}$ replaced by a predicted value $\hat{u}_{i t} \cdot \hat{u}_{i t}$ is constructed in the following way. 
Let $\Xi$ denote a $T \times K^{\prime}$ matrix of all exogenous variables (including the time dummies) as well as an instrument $I_{i t}$, with the properties

$$
\operatorname{plim} \frac{\varepsilon^{\prime} I}{T}=p \lim \frac{\mu^{\prime} I}{T}=0
$$

and $\quad \operatorname{plim} \frac{U^{\prime} I}{T} \neq 0$

where $I$ is the vector representation of $I_{\text {it }}{ }$

Assume $u$ may be written as

$$
u=\Xi \theta+\xi_{\mu}+\xi_{\varepsilon}
$$

where $\theta$ is a $K^{\prime} x 1$ vector of coefficients and

$$
\begin{aligned}
\operatorname{plim} \frac{\epsilon^{\prime} \xi_{\mu}}{T} & =p \operatorname{plim} \frac{\mu^{\prime} \xi_{\varepsilon}}{T}=0, \\
& \operatorname{plim} \frac{\epsilon^{\prime} \xi_{\epsilon}}{T} \neq 0, \operatorname{plim} \frac{\mu^{\prime} \xi_{\mu}}{T} \neq 0 \\
\text { and } \quad \operatorname{plim} \frac{\Xi^{\prime} \xi_{\mu}}{T} & =p \operatorname{plim} \frac{\Xi^{\prime} \xi_{\epsilon}}{T}=\operatorname{plim} \frac{\Xi^{\prime} \epsilon}{T}=\operatorname{plim} \frac{\Xi^{\prime} \mu}{T}=\underline{0},
\end{aligned}
$$

where $\underline{0}^{\prime}$ is the $1 \times \mathrm{K}^{\prime}$ vector $(0, \ldots, 0)$. (10) may be estimated using the random effects technique of the previous section. It then follows that

$$
\hat{u}_{i t}=\Xi_{i t} \hat{\theta} \text {. }
$$

Solving the problem of the endogeneity of $u$ thus involves estimating (8) twice; once using RE and once using REIV. For both estimations, both the first-step regression required to generate $\Lambda_{i t}$ and the second step regression that yields $\hat{\sigma}_{\epsilon}^{2}$ and $\hat{\sigma}_{\mu}^{2}$ are calculated using $\hat{\mathrm{u}}$ in the place of $u$. This ensures that the estimated covariance matrices are consistent. Depending on the outcome of Hausman's test, all further computation is done using either RE or REIV. 


\section{Some Geners1 Questions}

Once the problem of the endogeneity of $u$ is settled, and the appropriate estimation technique selected, several general questions can be addressed. Recall equation (5). Neglecting the subscripts $i$ and $t$ :

$$
\log \bar{w}=\bar{X} \beta+Y \gamma+u \sum_{s=1}^{S} \alpha_{s} Z \delta_{s} \cdot
$$

Proceeding from weakest to strongest restrictions on (11):

Q1: Does $\phi_{s}$ vary by skill group? That is, is $\delta_{s}=\delta$ for all $s$ ? If so,

(11) becomes

$$
\log \overline{\mathrm{w}}=\overline{\mathrm{X}} \beta+\mathrm{Y} \gamma+\mathrm{uZ} \delta \text {. }
$$

Cross-industry variation in $\phi=z \delta$ is not excluded.

Q2: Does $\phi_{s}$ vary by industry? This is equivalent to asking whether the inciusion in $\mathrm{Z}$ of any variable apart from a constant has any effect. variation in $\phi_{s}$ across skill groups is not excluded.

Q3: Does $\phi_{s}$ vary by skill or industry? Is $\phi_{s}=\phi$ where $\phi$ is constant? If so, (11) becomes

$$
\log \bar{w}=X \beta+Y \gamma+\phi u .
$$

Q4: Do union members receive higher average wages? The answer to this question of course depends on the answers to Q1-Q3. For example, if Q1-Q3 are all answered in the negative, Q4 is appropriately thought of as asking whether $\phi>0$ in (13). However, if Q1-Q3 are answered in the affirmative, Q4, in the sense of dealing with an average, must be approached by considering the interindustry distribution of $\phi_{\mathbf{S}}$. 


\section{The Data}

The data are comprised of annual average observations on 57 manufacturing, mining and forestry industries. For 30 of the industries, the time period covered was 1971-1976. Data for the other 27 industries were available only for the period 1971-1973. In the notation of the earlier sections: $T_{i}=6$ for $i=1, \ldots, 30 ; T_{i}=3$ for $i=31, \ldots, 57 ; T=261$; and $N=57$.

The hourly wage rate (in constant 1971 dollars) is gross of all deductions and includes overtime, bonuses, etc., and vacation pay. The other variables are

i) u--fraction of production workers covered by a collective agreement;

ii) F--fraction of production workers that are female;

iii) L--labor's share of value added;

iv) V--real value added per man-hour;

v) FS--average number of employees per reporting unit. ${ }^{14}$ (A rough measure of firm size.)

vi) $\alpha_{1}$--fraction of production workers that are skilled;

vii) $\alpha_{2}$--fraction of production workers that are semi-skilled; and vili) $\alpha_{3}$--fraction of production workers that are unskilled.

\section{Empirical Specification}

With the constraint $\Sigma_{s=1}^{s=s} \alpha_{s}=1$ imposed, (5) may be written

$$
\log \bar{w}_{i}=\bar{X}_{i} \beta+Y_{i} \gamma+u_{i} Z_{i} \delta_{1}+u_{i} \sum_{s=2}^{s} \alpha_{s_{i}} Z_{i}\left(\delta_{s}-\delta_{1}\right) .
$$


Given the list of variables in the previous section, worker characteristics $(\bar{X})$ are comprised of percent female (F). Characteristics of the firm (Y) are value added per man hour (V), included to proxy technological parameters as well as hedonic attributes such as the pace of work, and firm size (FS), included to take account of other dimensions of working conditions.

Recall that $\phi_{s}=\mathrm{Z} \delta_{s}$. $\mathrm{Z}$ is made up of: i) labor's share of value added (L), included as one determinant of the elasticity of demand for union labor; i1) union coverage, included to allow investigation of "coverage" and "threat" effects; and 1ii) percent female, included to pursue the question of whether unions exacerbate male-female wage differentials.

The equation to be estimated is therefore

$$
\begin{aligned}
& \log \bar{w}_{i t}=F_{i t} \beta_{0}+v_{i t} \gamma_{0}+F_{i t} \gamma_{1}+u_{i t} \delta_{11}+u_{i t} L_{i t} \delta_{12}+u_{i t}^{2} \delta_{13}+u_{i t} F_{i t} \delta_{14} \\
& +u_{i t} \alpha_{2 i t}\left(\delta_{21}-\delta_{11}\right)+u_{i t} \alpha_{2} L_{i t}\left(\delta_{22}-\delta_{12}\right) \\
& +u_{i t}^{2} \alpha_{2}\left(\delta_{23}-\delta_{13}\right)+u_{i t} \alpha_{2} F_{i t}\left(\delta_{24}-\delta_{14}\right) \\
& +u_{i t} \alpha_{3}\left(\delta_{31}-\delta_{11}\right)+u_{i t} \alpha_{3_{i t}} L_{i t}\left(\delta_{32}-\delta_{12}\right) \\
& +u_{i t}^{2} \alpha_{3}\left(\delta_{33}-\delta_{13}\right)+u_{i t} \alpha_{3} F_{i t}\left(\delta_{34}-\delta_{14}\right) \\
& +v_{71} D 71+\ldots+v_{76} D 76,
\end{aligned}
$$

where $D 71, \ldots, D 76$ denote the time dummies. The $\phi_{s}$ may be estimated by $\hat{\phi}_{s}=\mathrm{z} \hat{\delta}_{s}$. For $s=2$ and $s=3, \hat{\delta}_{s}$ must be inferred. That is, the regression. yields $\hat{\delta}_{1}, \widehat{\delta_{2}-\delta_{1}}$ and $\widehat{\delta_{3}-\delta_{1}}$. Accordingly $\hat{\delta}_{2}=\widehat{\delta}_{2}-\delta_{1}+\hat{\delta}_{1}$ and $\hat{\delta}_{3}=\widehat{\delta_{3}-\delta_{1}}+\hat{\delta}_{1}$. 
This complicates computation of the covariance matrix of $\hat{\delta}_{1}, \hat{\delta}_{2}$ and $\hat{\delta}_{3}$. The regression yields estimates of $\mathrm{v}\left(\hat{\delta}_{1}\right), \mathrm{V}\left(\delta_{\mathrm{s}}-\delta_{1}\right), \operatorname{Cov}\left(\hat{\delta}_{1}, \delta_{\mathrm{s}}-\delta_{1}\right)$ and $\operatorname{Cov}\left(\delta_{s}-\delta_{1}, \delta_{s}^{\prime}-\delta_{1}\right)\left(s_{,} s^{\prime}=2,3 ; s^{\prime} s^{\prime} !^{15}\right.$ It is easily demonstrated that for $8 \cdot=2,3$

$$
\begin{aligned}
\mathrm{v}\left(\hat{\delta}_{s}\right) & =\mathrm{v}\left(\widehat{\delta}_{s}-\delta_{1}\right)+\mathrm{v}\left(\hat{\delta}_{1}\right) \\
& +\operatorname{Cov}\left(\delta_{s}-\delta_{1}, \hat{\delta}_{1}\right)+\operatorname{Cov}\left(\delta_{s}-\delta_{1}, \hat{\delta}_{1}\right)^{\prime}
\end{aligned}
$$

Given $\mathrm{V}\left(\hat{\delta}_{\mathrm{s}}\right), \mathrm{V}\left(\hat{\phi}_{\mathrm{s}_{\text {it }}}\right)$ is constructed as $\mathrm{Z}_{i t} \mathrm{~V}\left(\hat{\delta}_{\mathrm{s}}\right) \mathrm{Z}_{i t}^{\prime}$. We are thus able to report standard errors for $\phi_{s_{i t}}$ as well as for various averages.

Before (15) can be estimated it is necessary to determine whether $u$ is endogenous.

To proceed in the manner outlined above, an instrument for $u$ is required. The instrument chosen was the variable

$$
I_{i t}=\left\{\begin{array}{rr}
1 & u_{i t}>\bar{u} \\
0 & u_{i t}=\bar{u} \\
-1 & u_{i t}<\bar{u}
\end{array}\right.
$$

where $\bar{u}$ is the arithmetic mean of the $u_{i t}{ }^{\circ}$ The simple correlation between $u_{i t}$ and $I_{i t}$ is $: 802$. The other variables in $\Xi$ were all the exogenous variables and the time dummies. $u_{i t}$ was assumed to have an error component structure of the same form as (8). The preliminary estimation indicated that, for $u_{i t}$, the hypothesis $\pi_{1}=\pi_{2}=0$ could not be rejected at the $1 \%$ significance level. Accordingly, no correction for heteroscedasticity was

made in the equation generating $\hat{u}_{\bullet}{ }^{16}$ The correlation between the actual and predicted values was $r_{u \hat{u}}=.828$. 
An initial instrumental variables regression (that is, simple OLS with $u$ replaced by $\hat{u}$ ) of (15) was computed to generate the heteroscedasticity correction for the wage equation, $\Lambda_{i t}$. The estimated values of $\pi_{1}$ and $\pi_{2}$ were

$$
\hat{\pi}_{1}=.075
$$

and

$$
\hat{\pi}_{2}=.231 \text {. }
$$

A weighted instrumental variables regression was then computed to obtain consistent estimates of $\sigma_{\sigma}^{2}$ and $\sigma_{\mu}^{2}$. The estimated values were

$$
\hat{\sigma}_{\epsilon}^{2}=.950 \times 10^{-3}
$$

and

$$
\hat{\sigma}_{\mu}^{2}=.694 \times 10^{-3}
$$

Note that $\hat{\sigma}_{\mu}^{2} /\left(\hat{\sigma}_{\sigma}^{2}+\hat{\sigma}_{\mu}^{2}\right) \cong .42$. That is, permanent unmeasured industry-specific effects account for about $42 \%$ of the unexplained variation in $10 g$ wages. Further, $\hat{\sigma}_{\mu}=.026$. Holding all measured factors constant, about one in twenty industries would therefore be expected to have $|\mu| \geq .05(\cong 1.96 \times .026)$. $\mu$ is not of second-order importance.

Using $\hat{\sigma}_{\varepsilon}^{2}$ and $\hat{\sigma}_{\mu}^{2}$, the full variance components estimation was undertaken using both REIV and RE techniques. Using the Hausman test the two equations were compared, and the hypothesis that $u$ is exogenous was rejected at any reasonable significance level. Accordingly, all further estimation employs the REIV method.

\section{Empirical Results}

Before discussing $\hat{\phi}_{s}$, it is necessary to consider how $\phi_{s}$ must be estimated. That 1s, should $\phi_{8}$ be treated as constant across industries, or across skill groups, or both, or neither? As stated above, questions $Q 1-Q 3$ may be formulated as restrictions on the general equation (15). The test 
employed was an asymptotic likelihood ratio test. That is, if $\&$ is the value of the unrestricted likelihood function and $£^{r}$ is the restricted likelihood value, then

$$
-2 \log \left(£^{\mathrm{r}} / £\right) \stackrel{\mathrm{A}}{\sim} \chi^{2}(q)
$$

where $q$ is the number of restrictions.

Table 1 presents the REIV regression results for the unrestricted and restricted equations. ${ }^{17} \mathrm{Q} 1-\mathrm{Q} 3$ are all rejected at size .05, although Q1, that $\phi_{s}$ does not vary across skill groups, is just barely rejected. We conclude therefore, that $\phi_{s}$ must be treated as varying across skill group and industries. Treating $\phi_{8}$ as constant across either $i$ or $t$ could thus involve a specification error.

Note that we have constrained $\phi_{s}$ to vary systematically with $Z$. Consequently, temporal'movement in $\phi_{s}$ is due to movement in $z$. The traditional view that $\phi_{8}$ varies countercyclically has often been tested as if $\phi_{8}$ had a Iife of its own, Independent of the structure that generates it. We do not subscribe to this approach.

As a result of space limitations, the complete list of $\hat{\phi}_{s}$ for all $s, i$ and $t$ is presented in the Appendix. The generating mechanism for $\hat{\phi}_{8}=z_{\text {it }} \hat{\delta}_{s}$ was inferred from the unrestricted REIV regressions (standard errors in parentheses):

and

$$
\begin{aligned}
& \hat{\phi}_{1}=\underset{(.1315)}{.1986}+\underset{(.0860)}{.1308 L}-\underset{(.1330)}{.1455 U}+\stackrel{.5943 F}{(.1612)} \\
& \hat{\phi}_{2}=\underset{(.0932)}{.1823}+\underset{(.0794)}{.0023 L}-\underset{(.0459 U}{.0938)}(.07817 F \\
& (.0787)
\end{aligned}
$$

$$
\hat{\phi}_{3}=\underset{(.0648)}{.4078}+\underset{(.0608)}{.0038 I}-\underset{(.0700)}{.2959 U}+\underset{(.0735)}{.1932 F}
$$


TABLE 1

REGRESSION RESULTS

Independent

Variable

\section{F}

V

FS

U

UL

$u^{2}$

UF

$\mathrm{Ua}_{2}$

$\mathrm{Ua}_{2} \mathrm{I}$

$u^{2} \alpha_{2}$

$\mathrm{Ud}_{2} \mathrm{~F}$

$\mathrm{Ua}_{3}$

$\mathrm{Ua}_{3} \mathrm{~L}$

$u^{2} \alpha_{3}$

$\mathrm{Ud}_{3} \mathrm{~F}$

$$
\begin{aligned}
& \text { Coefficients } \\
& \text { (standard errors in parentheses) }
\end{aligned}
$$

$-.2415$

(.0424)

.2688

(.0038)

.0000

(.00001)

.1986

(.1313)

.1308

$-.1455$

(.1332)

.5943

(.1613)

$-.0163$

(.1812)

$-.1286$

(.1458)

.0996

(.1947)

$-.3125$

(.1754)

.2092

(.1369)

$-.1270$

(.1024)

$-.1504$

(.1538)

$-.4011$

(.1756)

$$
\begin{aligned}
& -.2978 \\
& (.0344) \\
& .2660 \\
& (.0036) \\
& .0000 \\
& (.00001) \\
& .3284 \\
& (.0407) \\
& .0237 \\
& (.0226) \\
& -.02129 \\
& (.0337) \\
& . .3433 \\
& (.0544)
\end{aligned}
$$
.2660
$(.0036)$

$-.0616$

(.0093)

$-.05421$

(.0087)

.2725

(.0034)

.2715

(.0033)

.0000

$(.00001)$

.0000

$(.00001)$

.1200

$(.0228)$

.1498

$(.0167)$
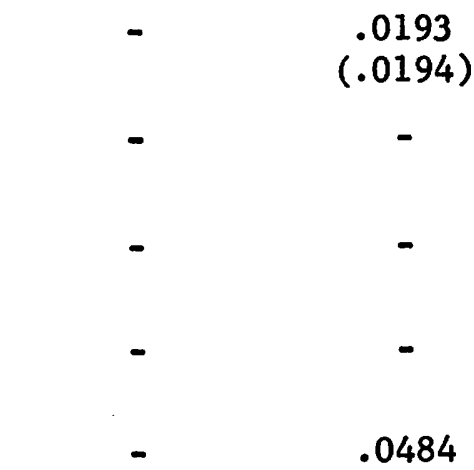

$(.0170)$

$\log$ likel thood (£) 678.74

670.82

646.61

641.84

number of restrictions(q) 0

8

9

11 
Although insignificant in each case, increasing labor's share of value added is predicted to raise $\phi_{s}$. This suggests, although we cannot be rigorous : with more than two factors of production, that on average the possibilities for substitution of one factor for another in production, are greater than the possibilities for substitution across goods in consumption. Put another way, for the industries under examination, it is not "important to be unimportant". Second the coefficient of $u$ is negative, indicating that as union coverage rises, spillovers to nonunion workers ("threat effects") are more important than the greater union power resulting from the decreased opportunity for consumers to substitute away from unionized firms (koverage effects').

Finally, the coefficient of $\mathrm{F}$ is positive, significant and monotonically increasing with skill. A possible explanation is simply that women both receive lower wages for each union status and tend not to unionize. Raising F thus creates a greater disparity between union and nonunion wages because the fraction of low wage workers in the nonunion group rises. The larger coefficient for the skilled and semi-skilled groups is consistent with this hypothesis if, as seems plausible, union membership is more difficult for women in high skell occupations. The question is of course whether raising $F$ allows women to capture any of the estimated gains. Given the current efforts to unionize office workers, this question is worthy of further investigation.

8. Intertemporal and Interindustry Variation in $\phi_{s}$

For each skill group and time period, $\phi_{s_{i t}}$ was averaged across industries. The average was the inverse variance weighted average 18 
(16)

$$
\hat{\phi}_{s_{t}}=\frac{1}{\sum_{i=1}^{N} 1 / v\left(\hat{\phi}_{s_{i t}}\right)} \cdot \sum_{i=1}^{N} \frac{\hat{\phi}_{s_{i t}}}{v\left(\hat{\phi}_{s_{i t}}\right)} .
$$

The results are displayed in Table 2

$$
\begin{aligned}
& \text { Table } 2 \\
& \hat{\phi}_{\mathrm{s}} \text { over time } \\
& \text { (standard errors in parentheses) }{ }^{\dagger}
\end{aligned}
$$

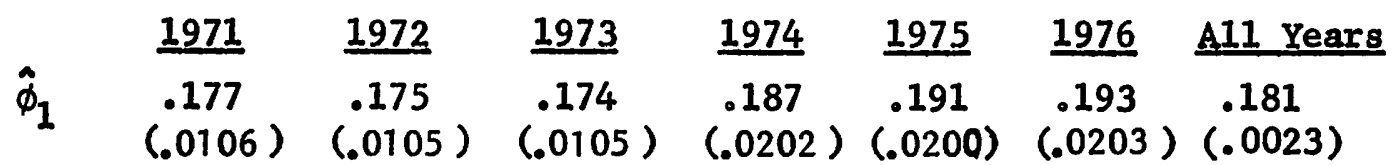

$$
\begin{aligned}
& \begin{array}{llllllll}
\hat{\phi}_{2} & .167 & (.167 & .168 & .173 & .174 & .176 & .170 \\
& (.0094) & (.0092) & (.0092) & (.0181) & (.0182) & (.0184) & (.0020)
\end{array} \\
& \begin{array}{llllllll}
\phi_{3} & .194 & .193 & .193 & .204 & .201 & .201 & .196 \\
& (.0074) & (.0073) & (.0074) & (.0139) & (.0137) & (.0138) & (.0016)
\end{array} \\
& \begin{array}{llllll}
\text { Price Level } 1.000 & 1.048 & 1.127 & 1.250 & 1.385 & 1.489
\end{array} \\
& (1971=1)
\end{aligned}
$$

The conventional wisdom that $\phi_{s}$ should fall during periods of rising inflation rates does not hold up well here. Indeed the more rapid inflation beginning In 1974 appears to have been adequately anticipated.

The results for all years agree with results found for the United States. ${ }^{19}$ That is, $\hat{\phi}_{3}>\hat{\phi}_{1}>\hat{\phi}_{2}$. The differences, while small, are of course significant in such a large sample.

Using the all years figures and average values of $\alpha_{1}, \alpha_{2}$ and $\alpha_{3}$ a grand average estimate of $\phi$ is .182 . Note that had we used the coefficient of $u$ in the final equation of Table 1 as an estimate of the grand average, we 
would have predicted .150 , nearly $20 \%$ below the appropriate figure. This basic specification error is one reason why our results are higher than the $.10-.14$ range typically found in the United States. Finally, for each industry, an average analogous to (16) was calcu1ated. The results are presented in the appendix in the same table as $\phi_{\mathbf{s}_{i t}}$. With very few exceptions, the $\hat{\phi}_{\mathbf{s}_{i}}$ are quite reasonable. The extreme values evidently reflect prediction far from the sample mean of the independent variables. The general conclusion is that the specification used herein is quite effective in capturing $\phi_{s} \cdot$

Summary

This paper has provided efficient estimates of union-nonunion wage differentials in Canada. Using a pooled time-series and cross-section model, the Important conclusions were that:

a) union coverage should be treated as an endogenous variable;

b) there are substantial unmeasured industry-specific permanent wage differentials;

c) wage differentials should be viewed as varying across skill groups and industries;

and d) the average wage effects are $19.8 \%, 18.5 \%$ and $21.7 \%$ for skilled, semi-skilled, and unskilled workers, respectively. 


\section{Footnotes}

$\dagger$

The authors are indebted to Geoffrey Carliner for helpful comments and Kevin B. Kerr for able research assistance.

${ }^{1}$ The various studies are surveyed in [2].

2 These estimates are from Table 2 and are computed as $e^{\hat{\phi}_{s}}-1$.

The algebra, if not the interpretation, is similar to that presented in $[10]$.

${ }^{4}$ The difference between $e^{\phi_{s}}-1$ and $\phi_{s}$ is small for $-.2<\phi_{8}<.2$. Accordingly most of our calculations are in terms of $\phi_{s}$, for which estimates of varlances etc. are available directly. If desired, the reader can compute $e^{\phi_{s}}-1$ and $v\left(e^{\phi_{s}}-b\right) \cong e^{2 \phi_{s}} \sigma_{\phi_{s}}^{2}$.

5 The analysis can be carried out using the arithmetic mean instead of the geometric mean. The results are typically very similar. See [10] for example.

${ }^{6}$ It should be noted that (5) has a number of economic interpretations. The traditional argument [7] suggests that union workers share monopoly rents as a result of the union's facing a downward sloping demand curve. A recent alternative 18 to approach (5) from the hedonic viewpoint. See [13] for the general theory, and [1] for its application to unions.

${ }^{7}$ Strictly speaking, the model should therefore be called an "unbalanced" error components model. See [3]. 
${ }^{8}$ For notational convenience the asterisks will not be used below. From this point onwards, the discussion will proceed as if the heteroscedasticity correction had been made.

${ }^{9}$ This is an easy extension of the discussion in [4].

${ }^{10}$ If $\hat{\eta}_{\text {It }}$ is computed from an OLS regression, $\hat{\eta}_{0} .=0$. However, if $\hat{h}_{\text {It }}$ is computed by applying instrumental variables coefficients to the righthand side variables, $\hat{\eta}_{0} .=0$ does not apply.

11. Precisely, $\lim _{N \rightarrow \infty} T_{0}=$ average number of observations per industry. 12 Note that, from (5) $u$ enters $\Omega$ is several places.

${ }^{13} \mathrm{~A}$ detailed description of the data is given in the appendix. The full data set is available from the authors on request.

${ }^{14} \mathrm{FS}$ is essentially an input measure of firm size. It is an accurate measure only if capital labor ratio is constant across industries. An output measure of size, value added per reporting unit, was also tried. The results were unchanged.

${ }^{15}$ Note that $\operatorname{cov}(.,$.$) is not symmetric.$

${ }^{16}$ At this point, the heteroscedasticity correction is not strictly necessary, since what we need is a consistent prediction $\hat{u}$. Consistency is not lost if heteroscedasticity is ignored.

17 As these regressions are fairly expensive to compute, the $v_{t}$ were consistently estimated from the weighted instrumental variable regression. The dependent variable for the full regression was $10 g w_{i t}-\hat{v}_{t} \cdot$. Some experimentation failed to yield any instance in which this simplification made anything more than a minute difference. 
18 This type of average is a minimum mean squared error estimator for the mean of a heteroscedastic population. If $V\left(\phi_{s i t}\right)$ is constant, $\hat{\phi}_{s_{t}}$ collapses to the arithmetic mean. ${ }^{19}$ See, for example, [10]. 


\section{References}

[1] Duncan, G. J. and Stafford, F. P. "Do Union Members Receive Compensating Wage Differentials?" undated.

[2] Evans, J. C. and MacDonald, G. M. "On Estimating the Union-Nonunion Wage Differential in Canada." Presented at the Canadian Economic Association. Meetings, May 1976.

[3] Graybill, F. A. An Introduction to Linear Statistical Models. New York: McGraw-Hil1, 1961.

[4] Hausman, J. A. "Specification Tests in Econometrics." Econometrica, 46 (November, 1978), 1251-1271.

[5] Institut National de la Statistique et des Etudes Economiques. The Econometrics of Panel Data. Paris: INSEE, 1977.

[6] Kumar, P. "Differentials in Wage Rates of Unskilled Labour in Canadian Manufacturing Industries." Industrial and Labour Relations Review, 25 (June 1972), 631-645.

[7] Lewis, H. G. Unionism and Relative Wages in the United States. Chicago: University of Chicago Press, 1963.

[8] Maddala, G. S. "The Use of Variance Components Models in Pooling Cross Section and Time Series Data." Econometrica, 39 (March 1971), 341-358.

[9] Mundlak, Y. "On the Pooling of Time Series and Cross Section Data." Econometrica, 46 (January 1978), 69-85.

[10] Rosen, S. "Trade Union Power, Threat Effects and the Extent of Organization." Review of Economic Studies, 36 (April 1969), 185-196.

[11] Rosen, S. "Unionism and the Occupational Wage Structure in the United States." International Economic Review, 11 (June 1970), 269-286.

[12] Rosen, S. "On the Interindustry Wage and Hours Structure." Journal of Political : Economy, 77 (March/April 1969), 249-273. 
[13] Rosen, S. "Hedonic Prices and Implicit Markets: Product Differentiation in Pure Competition." Journal of Political Economy, 82 (January/February 1974), 34-55.

- [14] Starr, G. F. Union-Nonunion Wage Differentials: A Cross Sectional Analysis. Ontario Ministry of Labour, 1973.

[15] Wallace, T. D. and Hussain, A. "The Use of Error Components Models in Combining Cross Section with Time Series Data." Econometrica, 37 (January 1969), 55-72. 
APPENDIX

I. Variables and Their Definitions

Real Wage: (W)

This variable is constructed by dividing total production and related workers' wages by total hours paid for each industry. This is then divided by the consumer price index, (C.P.I.).

Total wages comprise all man-hours paid including regular work, overtime, and paid leave as well as bonuses, commissions, etc., paid to regular employees. Values are reported before deductions for income tax and employee benefits. $[1,2,3,4]$.

Proportion of Female Production Employment: (F)

This variable is constructed by dividing total female production employment by tofal production and related employment.

Production and related employment includes those employees at the establishment engaged in processing, assembling, storing, inspecting, handling, packing maintenance, repair, janitorial and watchman services and working foremen. $[1,2,3]$.

\section{Real Value Added Per Man-Hour Paid: (V)}

This variable is constructed by dividing value added in production by total hours paid. This figure is then divided by the C.P.I.

Value added in production is measured by value of shipments of goods of own manufacture plus net change in inventory of goods in process and finished goods, less cost of materials and supplies used, fuel and electricity. $[1,2,3,4]$. 
Firm Size: (FS)

This variable is constructed by dividing total production and related employment by the number of reporting units.

A reporting unit is defined as the smallest operating unit capable of reporting certain specific input and output data (materials and supplies used, goods purchased for resale as such, fuel and power consumed, number of employees and their pay, inventories and shipments or sales), usually a plant or mill. $[1,2,3,4]$.

Proportion of Non-Office Employees (Excluding Sales) Covered by a Collective Agreement: (U)

This refers to the proportion of production employees actually covered by collective agreements. [5].

Labour's Share of Value Added: (L)

This variable is constructed by dividing total wages and salaries by value added in production. $[1,2,3]$.

Proportion of Skilled Employees: $\left(\alpha_{1}\right)$

These are production employees who have a specific vocational preparation (S.V.P.) classification of 7-9. This requires more than two years of specific training.

This proportion is constructed by dividing skilled production employment by total occupational production employment. $[6,7]$.

Proportion of Semi-Skilled Employees: $\left(\alpha_{2}\right)$

These are production employees who have a S.V.P. classification of 4-6. This requires specific training of more than three months but no more than two years.

This proportion is constructed by dividing semi-skilled production employment by total occupational production employment. $[6,7]$. 
Proportion of Unskilled Employees: $\left(\alpha_{3}\right)$

These are production employees with a S.V.P. classification of 1-3. The time requirement for specific training under this group is no more than three months. This proportion is easily constructed as $1-\alpha_{2}-\alpha_{1}$. $[6,7]$

Note: Due to the unavailability of employment figures by occupation in 1974, $\alpha_{1}, \alpha_{2}$ and $\alpha_{3}$ are estimated using a geometric average of the 1973 and 1975 figures. This is only done for the first 30 industries examined. 


\section{Sources}

[1] General Review of the Mineral Industries: Mines, Quarries and Oil Wells, Annual Census of Mines, The Ministry of Industry, Trade and Commerce, Statistics Canada, Manufacturing and Primary Industry Division, Ottawa, $1971-1973$.

[2] Logging, Annual Census of Forestry, The Ministry of Industry, Trade and Commerce, Statistics Canada, Manufacturing and Primary Industries Division, Ottawa, 1971-1973.

Note: The industry, Logging Eastern Canada (industry No. 31) includes statistics for Nova Scotia for 1973 only.

[3] Manufacturing Industries of Canada - National and Provincial Areas, The Ministry of Industry, Trade and Commerce, Statistics Canada, Manufacturing and Primary Industries Division, Ottawa, 1971-1976. Note: Where required, manufacturing industries were aggregated. For example, Hosiery and Other Knitted Goods, industry No. 9, involves the aggregate of S.I.C.'s 231 and 239.

[4] Consumex Prices and Price Indexes, The Ministry of Industry, Trade and Commerce, Statistics Canada, Prices Division, Ottawa, 1971-1976.

[5] Working Conditions in Canadian Industry, Labour Data, Labour Canada, Supply and Services Canada, Ottawa, 1971-1976.

[6] Wage Rates, Salaries and Hours of Labour, Surveys Division, Economics and Research Branch, Canada Department of Labour, Ottawa, Canada, 1971-1976. Note: Figures on employees by occupation include both time and piecework employment.

[7] Canadian Classification and Dictionary of Occupations, The Ministry of Manpower and Immigration, 1971. 
II.

Characteristics of Variables in Equation (19).

Variable

Mean

S.D.

W

1.2157

0.2400

F

0.2053

0.2491

V

3.4679

0.7970

FS

139.207

221.041

U

0.7305

0.1959

L

0.3830

0.1131

$\alpha_{1}$

0.1774

0.1742

$\alpha_{2}$

0.4389

0.2025

$\alpha_{3}$

0.3837

0.2285

UL

0.2775

0.1067

$\mathrm{u}^{2}$

0.5720

0.2542

Ư

0.1268

0.1468

$\mathrm{U} \alpha_{2}$

0.3176

0.1620

$\mathrm{U} \alpha_{2} \mathrm{~L}$

0.1232

0.0715

$\mathrm{U}^{2} \alpha_{2}$

0.2474

0.1561

$\mathrm{Ua}{ }_{2} \mathrm{~F}$

0.0634

0.0948

$\mathrm{Ua}_{3}$

0.2733

0.1709

$\mathrm{Ua}_{3} \mathrm{~L}$

0.1026

0.0712

$u^{2} \alpha_{3}$

0.2083

0.1494

$\mathrm{U} \alpha_{3} \mathrm{~F}$

0.0537

0.0757

Note: The variable denoted $U$ and its interactions refer to the actual variable $U$ as opposed to the predicted value $\hat{U}$. $U$ is the appropriate variable to use for experimentation with the estimated coefficients. 
III.

Estimated $\phi_{s_{\text {it }}}$ (Standard Errors in Parentheses)

Table 1

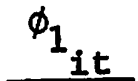

\begin{tabular}{|c|c|c|c|c|c|c|c|c|}
\hline & & & & & & & & \\
\hline $\begin{array}{l}\text { Industry } \\
\text { (i) }\end{array}$ & $\begin{array}{l}\text { Time } \\
(t)\end{array}$ & 1971 & 1972 & 1973 & 1974 & 1975 & 1976 & $\begin{array}{l}\text { over } \\
\text { time }\end{array}$ \\
\hline $\begin{array}{l}\text { siaughtering and Meat } \\
\text { Processors }\end{array}$ & & $\begin{array}{l}0.228 \\
(0.0326)\end{array}$ & $\begin{array}{l}0.225 \\
(0.0327)\end{array}$ & $\begin{array}{l}0.219 \\
(0.0313)\end{array}$ & $\begin{array}{l}0.218 \\
(0.0329)\end{array}$ & $\begin{array}{l}0.221 \\
(0.0328)\end{array}$ & $\begin{array}{l}0.217 \\
(0.0341)\end{array}$ & $\begin{array}{l}0.221 \\
(0.0134)\end{array}$ \\
\hline $\begin{array}{l}\text { Fish Products } \\
\text { Industries }\end{array}$ & & $\begin{array}{l}0.358 \\
(0.0467)\end{array}$ & $\begin{array}{l}0.370 \\
(0.0495)\end{array}$ & $\begin{array}{l}0.371 \\
(0.0533)\end{array}$ & $\begin{array}{l}0.382 \\
(0.0551)\end{array}$ & $\begin{array}{l}0.390 \\
(0.0561)\end{array}$ & $\begin{array}{l}0.404 \\
(0.0581)\end{array}$ & $\begin{array}{l}0.377 \\
(0.0215)\end{array}$ \\
\hline $\begin{array}{l}\text { Dairy Products } \\
\text { Industries }\end{array}$ & & $\begin{array}{l}0.187 \\
(0.0440)\end{array}$ & $\begin{array}{l}0.182 \\
(0.0372)\end{array}$ & $\begin{array}{l}0.185 \\
(0.0363)\end{array}$ & $\begin{array}{l}0.182 \\
(0.0366)\end{array}$ & $\begin{array}{l}0.177 \\
(0.0333)\end{array}$ & $\begin{array}{l}0.184 \\
(0.0352)\end{array}$ & $\begin{array}{l}0.182 \\
(0.0150)\end{array}$ \\
\hline $\begin{array}{l}\text { Grain Mill Products } \\
\text { Industries }\end{array}$ & & $\begin{array}{l}0.175 \\
(0.0398)\end{array}$ & $\begin{array}{l}0.187 \\
(0.0494)\end{array}$ & $\begin{array}{l}0.173 \\
(0.0393)\end{array}$ & $\begin{array}{l}0.175 \\
(0.0416)\end{array}$ & $\begin{array}{l}0.175 \\
(0.0383)\end{array}$ & $\begin{array}{l}0.174 \\
(0.0356)\end{array}$ & $\begin{array}{l}0.176 \\
(0.1640)\end{array}$ \\
\hline $\begin{array}{l}\text { Bakery Products } \\
\text { Induotries }\end{array}$ & & $\begin{array}{l}0.343 \\
(0.0460)\end{array}$ & $\begin{array}{l}0.340 \\
(0.0451)\end{array}$ & $\begin{array}{l}0.332 \\
(0.0451)\end{array}$ & $\begin{array}{l}0.333 \\
(0.0465)\end{array}$ & $\begin{array}{l}0.326 \\
(0.0452)\end{array}$ & $\begin{array}{l}0.322 \\
(0.0428)\end{array}$ & $\begin{array}{c}0.332 \\
(0.0184)\end{array}$ \\
\hline $\begin{array}{l}\text { Soft Drink Manu- } \\
\text { facturing }\end{array}$ & & $\begin{array}{l}0.185 \\
(0.0628)\end{array}$ & $\begin{array}{l}0.181 \\
(0.0606)\end{array}$ & $\begin{array}{l}0.176 \\
(0.0560)\end{array}$ & $\begin{array}{l}0.175 \\
(0.0486)\end{array}$ & $\begin{array}{l}0.177 \\
(0.0531)\end{array}$ & $\begin{array}{l}0.179 \\
(0.0521)\end{array}$ & $\begin{array}{c}0.178 \\
(0.0224)\end{array}$ \\
\hline Breweries & & $\begin{array}{l}0.084 \\
(0.0304)\end{array}$ & $\begin{array}{l}0.081 \\
(0.0309)\end{array}$ & $\begin{array}{l}0.080 \\
(0.0303)\end{array}$ & $\begin{array}{l}0.080 \\
(0.0300)\end{array}$ & $\begin{array}{l}0.086 \\
(0.0286)\end{array}$ & $\begin{array}{l}0.085 \\
(0.0293)\end{array}$ & $\begin{array}{l}0.083 \\
(0.0122)\end{array}$ \\
\hline Shoe Factorles & - & $\begin{array}{l}0.540 \\
(0.0767)\end{array}$ & $\begin{array}{l}0.537 \\
(0.0788)\end{array}$ & $\begin{array}{c}0.548 \\
(0.0785)\end{array}$ & $\begin{array}{c}0.553 \\
(0.0817)\end{array}$ & $\begin{array}{c}0.554 \\
(0.0777)\end{array}$ & $\begin{array}{l}0.543 \\
(0.0808)\end{array}$ & $\begin{array}{l}0.546 \\
(0.0322)\end{array}$ \\
\hline $\begin{array}{l}\text { Hosiery and Knitting } \\
\text { Mills }\end{array}$ & & $\begin{array}{l}0.596 \\
(0.0855)\end{array}$ & $\begin{array}{l}0.586 \\
(0.0850)\end{array}$ & $\begin{array}{l}0.587 \\
(0.0838)\end{array}$ & $\begin{array}{l}0.587 \\
(0.0835)\end{array}$ & $\begin{array}{l}0.600 \\
(0.0865)\end{array}$ & $\begin{array}{l}0.606 \\
(0.0876)\end{array}$ & $\begin{array}{l}0.593 \\
(0.0348)\end{array}$ \\
\hline $\begin{array}{l}\text { Men's Clothing } \\
\text { Industries }\end{array}$ & & $\begin{array}{l}0.626 \\
(0.1004)\end{array}$ & $\begin{array}{l}0.638 \\
(0.1010)\end{array}$ & $\begin{array}{l}0.642 \\
(0.1031)\end{array}$ & $\begin{array}{l}0.644 \\
(0.1061)\end{array}$ & $\begin{array}{l}0.631 \\
(0.1064)\end{array}$ & $\begin{array}{l}0.630 \\
(0.1064)\end{array}$ & $\begin{array}{l}0.635 \\
(0.0424)\end{array}$ \\
\hline $\begin{array}{l}\text { Women's Clothing } \\
\text { Industries }\end{array}$ & & $\begin{array}{l}0.683 \\
(0.1092)\end{array}$ & $\begin{array}{l}0.681 \\
(0.1094)\end{array}$ & $\begin{array}{l}0.682 \\
(0.1090)\end{array}$ & $\begin{array}{l}0.682 \\
(0.1095)\end{array}$ & $\begin{array}{l}0.679 \\
(0.1062)\end{array}$ & $\begin{array}{l}0.668 \\
(0.1055)\end{array}$ & $\begin{array}{l}0.679 \\
(0.0441)\end{array}$ \\
\hline $\begin{array}{l}\text { Children's Clothing } \\
\text { Industries }\end{array}$ & & $\begin{array}{l}0.701 \\
(0.1029)\end{array}$ & $\begin{array}{l}0.719 \\
(0.1048)\end{array}$ & $\begin{array}{l}0.710 \\
(0.1037)\end{array}$ & $\begin{array}{l}0.715 \\
(0.1046)\end{array}$ & $\begin{array}{l}0.704 \\
(0.1045)\end{array}$ & $\begin{array}{c}0.712 \\
(0.1069)\end{array}$ & $\begin{array}{l}0.710 \\
(0.0427)\end{array}$ \\
\hline $\begin{array}{l}\text { Saw Mills, Planing Mills } \\
\text { and Shingle Mills }\end{array}$ & & $\begin{array}{l}0.169 \\
(0.0389)\end{array}$ & $\begin{array}{l}0.160 \\
(0.0403)\end{array}$ & $\begin{array}{l}0.148 \\
(0.0374)\end{array}$ & $\begin{array}{l}0.163 \\
(0.0345)\end{array}$ & $\begin{array}{c}0.171 \\
(0.0352)\end{array}$ & $\begin{array}{l}0.167 \\
(0.0333)\end{array}$ & $\begin{array}{l}0.163 \\
(0.0148)\end{array}$ \\
\hline $\begin{array}{l}\text { Household Office and } \\
\text { Other Furniture Mnfs. }\end{array}$ & & $\begin{array}{l}0.249 \\
(0.0389)\end{array}$ & $\begin{array}{l}0.259 \\
(0.0395)\end{array}$ & $\begin{array}{l}0.265 \\
(0.0402)\end{array}$ & $\begin{array}{l}0.273 \\
(0.0378)\end{array}$ & $\begin{array}{l}0.276 \\
(0.0360)\end{array}$ & $\begin{array}{l}0.286 \\
(0.0369)\end{array}$ & $\begin{array}{l}0.269 \\
(0.0156)\end{array}$ \\
\hline $\begin{array}{l}\text { Paper Box and Bag } \\
\text { Manufacturers }\end{array}$ & & $\begin{array}{l}0.270 \\
(0.0379)\end{array}$ & $\begin{array}{c}0.271 \\
(0.0371)\end{array}$ & $\begin{array}{l}0.271 \\
(0.0362)\end{array}$ & $\begin{array}{l}0.265 \\
(0.0358)\end{array}$ & $\begin{array}{l}0.273 \\
(0.0367)\end{array}$ & $\begin{array}{l}0.266 \\
(0.0365)\end{array}$ & $\begin{array}{l}0.269 \\
(0.0150)\end{array}$ \\
\hline Iron and Steel Mills & & $\begin{array}{l}0.144 \\
(0.0337)\end{array}$ & $\begin{array}{l}0.146 \\
(0.0328)\end{array}$ & $\begin{array}{l}0.142 \\
(0.0328)\end{array}$ & $\begin{array}{l}0.140 \\
(0.0320)\end{array}$ & $\begin{array}{l}0.158 \\
(0.0367)\end{array}$ & $\begin{array}{c}0.153 \\
(0.0331)\end{array}$ & $\begin{array}{l}0.147 \\
(0.0136)\end{array}$ \\
\hline $\begin{array}{l}\text { Fabricated Structural } \\
\text { - Metal Industry }\end{array}$ & & $\begin{array}{l}0.127 \\
(0.0268)\end{array}$ & $\begin{array}{l}0.144 \\
(0.0293)\end{array}$ & $\begin{array}{l}0.126 \\
(0.0263)\end{array}$ & $\begin{array}{l}0.117 \\
(0.0256)\end{array}$ & $\begin{array}{c}0.121 \\
(0.0256)\end{array}$ & $\begin{array}{l}0.120 \\
(0.0271)\end{array}$ & $\begin{array}{c}0.125 \\
(0.0109)\end{array}$ \\
\hline $\begin{array}{l}\text { Ornamental and Archi- } \\
\text { tectural Metal Ind. }\end{array}$ & & $\begin{array}{l}0.193 \\
(0.0393)\end{array}$ & $\begin{array}{l}0.200 \\
(0.0387)\end{array}$ & $\begin{array}{c}0.214 \\
(0.0431)\end{array}$ & $\begin{array}{l}0.198 \\
(0.0378)\end{array}$ & $\begin{array}{l}0.189 \\
(0.0309)\end{array}$ & $\begin{array}{l}0.190 \\
(0.0325)\end{array}$ & $\begin{array}{c}0.196 \\
(0.0148)\end{array}$ \\
\hline
\end{tabular}


Table 1 (cont 'd.)

\begin{tabular}{|c|c|c|c|c|c|c|c|c|}
\hline $\begin{array}{l}\text { Industry } \\
\text { (1) }\end{array}$ & $\begin{array}{r}\text { Time } \\
(t)\end{array}$ & 1971 & 1972 & 1973 & 1974 & 1975 & 1976 & $\begin{array}{l}\text { Average } \\
\text { over } \\
\text { time }\end{array}$ \\
\hline $\begin{array}{l}\text { Metal Stamping, Process } \\
\text { and Coating Industry }\end{array}$ & & $\begin{array}{l}0.215 \\
(0.0332)\end{array}$ & $\begin{array}{l}0.215 \\
(0.0320)\end{array}$ & $\begin{array}{l}0.216 \\
(0.0319)\end{array}$ & $\begin{array}{l}0.219 \\
(0.0337)\end{array}$ & $\begin{array}{l}0.218 \\
(0.0309)\end{array}$ & $\begin{array}{l}0.221 \\
(0.0311)\end{array}$ & $\begin{array}{l}0.217 \\
(0.0131)\end{array}$ \\
\hline $\begin{array}{l}\text { Wire and Wire Products } \\
\text { Manufacturers }\end{array}$ & & $\begin{array}{c}0.211 \\
(0.0286)\end{array}$ & $\begin{array}{l}0.210 \\
(0.0286)\end{array}$ & $\begin{array}{l}0.202 \\
(0.0284)\end{array}$ & $\begin{array}{l}0.190 \\
(0.0286)\end{array}$ & $\begin{array}{l}0.187 \\
(0.0294)\end{array}$ & $\begin{array}{l}0.202 \\
(0.0294)\end{array}$ & $\begin{array}{l}.0 .200^{\circ} \\
(0.0118)\end{array}$ \\
\hline Machine Shops & & $\begin{array}{l}0.226 \\
(0.0786)\end{array}$ & $\begin{array}{l}0.208 \\
(0.0680)\end{array}$ & $\begin{array}{l}0.216 \\
(0.0710)\end{array}$ & $\begin{array}{l}0.212 \\
(0.0643)\end{array}$ & $\begin{array}{l}0.229 \\
(0.0708)\end{array}$ & $\begin{array}{l}0.235 \\
(0.0748)\end{array}$ & $\begin{array}{l}0.220 \\
(0.0289)\end{array}$ \\
\hline $\begin{array}{l}\text { Agricultural Implement } \\
\text { Industry }\end{array}$ & & $\begin{array}{l}0.137 \\
(0.0280)\end{array}$ & $\begin{array}{l}0.137 \\
(0.0278)\end{array}$ & $\begin{array}{l}0.157 \\
(0.0327)\end{array}$ & $\begin{array}{l}0.134 \\
(0.0269)\end{array}$ & $\begin{array}{l}0.141 \\
(0.0275)\end{array}$ & $\begin{array}{l}0.136 \\
(0.0296)\end{array}$ & $\begin{array}{l}0.139 \\
(0.0117)\end{array}$ \\
\hline $\begin{array}{l}\text { Misc. Machinery and Equip } \\
\text { ment Manufacturers }\end{array}$ & & $\begin{array}{l}0.162 \\
(0.0292)\end{array}$ & $\begin{array}{l}0.169 \\
(0.0297)\end{array}$ & $\begin{array}{l}0.161 \\
(0.0280)\end{array}$ & $\begin{array}{l}0.154 \\
(0.0267)\end{array}$ & $\begin{array}{l}0.154 \\
(0.0258)\end{array}$ & $\begin{array}{l}0.159 \\
(0.0260)\end{array}$ & $\begin{array}{l}0.159 \\
(0.0112)\end{array}$ \\
\hline $\begin{array}{l}\text { Aircraft and Aircraft } \\
\text { Parts Manufacturers }\end{array}$ & & $\begin{array}{l}0.137 \\
(0.0265)\end{array}$ & $\begin{array}{c}0.141 \\
(0.0263)\end{array}$ & $\begin{array}{l}0.142 \\
(0.0259)\end{array}$ & $\begin{array}{l}0.162 \\
(0.0265)\end{array}$ & $\begin{array}{l}0.158 \\
(0.0260)\end{array}$ & $\begin{array}{l}0.148 \\
(0.0264)\end{array}$ & $\begin{array}{l}0.148 \\
(0.0107)\end{array}$ \\
\hline $\begin{array}{l}\text { Motor Vehicle Parts and } \\
\text { Accessories Minfrs. }\end{array}$ & & $\begin{array}{l}0.221 \\
(0.0375)\end{array}$ & $\begin{array}{l}0.231 \\
(0.0361)\end{array}$ & $\begin{array}{l}0.235 \\
(0.0391)\end{array}$ & $\begin{array}{l}0.235 \\
(0.0390)\end{array}$ & $\begin{array}{l}0.215 \\
(0.0329)\end{array}$ & $\begin{array}{c}0.221 \\
(0.0349)\end{array}$ & $\begin{array}{l}0.225 \\
(0.0148)\end{array}$ \\
\hline Shipbuilding and Repair & & $\begin{array}{l}0.134 \\
(0.0336)\end{array}$ & $\begin{array}{l}0.138 \\
(0.0345)\end{array}$ & $\begin{array}{l}0.138 \\
(0.0364)\end{array}$ & $\begin{array}{l}0.137 \\
(0.0324)\end{array}$ & $\begin{array}{l}0.138 \\
(0.0344)\end{array}$ & $\begin{array}{l}0.139 \\
(0.0355)\end{array}$ & $\begin{array}{l}0.137 \\
(0.0140)\end{array}$ \\
\hline $\begin{array}{l}\text { Communications Equip- } \\
\text { ment Manufacturers }\end{array}$ & $\cdot$ & $\begin{array}{l}0.443 \\
(0.0787)\end{array}$ & $\begin{array}{l}0.440 \\
(0.0766)\end{array}$ & $\begin{array}{l}0.458 \\
(0.0795)\end{array}$ & $\begin{array}{l}0.449 \\
(0.0804)\end{array}$ & $\begin{array}{l}0.413 \\
(0.0749)\end{array}$ & $\begin{array}{l}0.423 \\
(0.0742)\end{array}$ & $\begin{array}{l}0.437 \\
(0.0316)\end{array}$ \\
\hline $\begin{array}{l}\text { Mnfrs. of Electrical } \\
\text { Industrial Equipt. }\end{array}$ & & $\begin{array}{l}0.255 \\
(0.0394)\end{array}$ & $\begin{array}{l}0.264 \\
(0.0443)\end{array}$ & $\begin{array}{l}0.285 \\
(0.0441)\end{array}$ & $\begin{array}{l}0.262 \\
(0.0459)\end{array}$ & $\begin{array}{l}0.244 \\
(0.0429)\end{array}$ & $\begin{array}{l}0.265 \\
(0.0438)\end{array}$ & $\begin{array}{c}0.262^{z} \\
(0.0177)\end{array}$ \\
\hline Petroleum Refineries & & $\begin{array}{l}0.089 \\
(0.0309)\end{array}$ & $\begin{array}{l}0.094 \\
(0.0315)\end{array}$ & $\begin{array}{l}0.090 \\
(0.0320)\end{array}$ & $\begin{array}{l}0.089 \\
(0.0352)\end{array}$ & $\begin{array}{l}0.119 \\
(0.0462)\end{array}$ & $\begin{array}{l}0.126 \\
(0.0518)\end{array}$ & $\begin{array}{l}0.096 \\
(0.0146)\end{array}$ \\
\hline $\begin{array}{l}\text { Mnfrs. of Industrial } \\
\text { Chemicals }\end{array}$ & & $\begin{array}{c}0.112 \\
(0.0281)\end{array}$ & $\begin{array}{l}0.112 \\
(0.0276)\end{array}$ & $\begin{array}{l}0.110 \\
(0.0297)\end{array}$ & $\begin{array}{l}0.105 \\
(0.0319)\end{array}$ & $\begin{array}{l}0.103 \\
(0.0304)\end{array}$ & $\begin{array}{l}0.110 \\
(0.0306)\end{array}$ & $\begin{array}{l}0.109 \\
(0.0121)\end{array}$ \\
\hline Logging Eastern Canada & & $\begin{array}{l}0.170 \\
(0.0357)\end{array}$ & $\begin{array}{l}0.163 \\
(0.0341)\end{array}$ & $\begin{array}{l}0.156 \\
(0.0324)\end{array}$ & & & & $\begin{array}{l}0.162 \\
(0.0196)\end{array}$ \\
\hline Logging British Columbia & & $\begin{array}{c}0.1138 \\
(0.0277)\end{array}$ & $\begin{array}{l}0.129 \\
(0.0266)\end{array}$ & $\begin{array}{l}0.106 \\
(0.0285)\end{array}$ & & & & $\begin{array}{l}0.125 \\
(0.0159)\end{array}$ \\
\hline Gold-Quartz Mining & & $\begin{array}{l}0.150 \\
(0.0310)\end{array}$ & $\begin{array}{l}0.137 \\
(0.0281)\end{array}$ & $\begin{array}{l}0.119 \\
(0.0271)\end{array}$ & & & & $\begin{array}{l}0.134 \\
(0.0165)\end{array}$ \\
\hline Iron & & $\begin{array}{l}0.079 \\
(0.0304)\end{array}$ & $\begin{array}{l}0.089 \\
(0.0281)\end{array}$ & $\begin{array}{l}0.092 \\
(0.0283)\end{array}$ & & & & $\begin{array}{l}0.087 \\
(0.0167)\end{array}$ \\
\hline Other Metals & & $\begin{array}{c}0.099 \\
(0.0269)\end{array}$ & $\begin{array}{c}0.096 \\
(0.0270)\end{array}$ & $\begin{array}{c}0.087 \\
(0.0305)\end{array}$ & & & & $\begin{array}{c}0.094 \\
(0.0162)\end{array}$ \\
\hline Coal & & $\begin{array}{l}0.214 \\
(0.0803)\end{array}$ & $\begin{array}{l}0.117 \\
(0.0280)\end{array}$ & $\begin{array}{l}0.111 \\
(0.0258)\end{array}$ & & & & $\begin{array}{l}0.119 \\
(0.0184)\end{array}$ \\
\hline
\end{tabular}


Table 1 (cont 'd.)

\begin{tabular}{|c|c|c|c|c|c|c|c|}
\hline $\begin{array}{c}\text { Industry } \\
(1)\end{array}$ & $\begin{array}{l}\text { Time } \\
(t)\end{array}$ & 1972 & 1973 & 1974 & 1975 & 1976 & \begin{tabular}{|l} 
Average \\
over \\
time
\end{tabular} \\
\hline Biscuit Manufacturers & $\begin{array}{c}0.472 \\
(0.0859)\end{array}$ & $\begin{array}{c}0.492 \\
(0.0824)\end{array}$ & $\begin{array}{l}0.488 \\
(0.0875)\end{array}$ & & & & $\begin{array}{c}0.484 \\
(0.0492)\end{array}$ \\
\hline Confectionery Mnfrs. & $\begin{array}{c}0.467 \\
(0.0781)\end{array}$ & $\begin{array}{c}0.458 \\
(0.0816)\end{array}$ & $\begin{array}{c}0.459 \\
(0.0851)\end{array}$ & & & & $\begin{array}{c}0.461 \\
(0.0470)\end{array}$ \\
\hline $\begin{array}{l}\text { Tobacco Products } \\
\text { Manufacturers }\end{array}$ & $\begin{array}{l}0.379 \\
(0.0892)\end{array}$ & $\begin{array}{l}0.367 \\
(0.0890)\end{array}$ & $\begin{array}{l}0.366 \\
(0.0870)\end{array}$ & & & & $\begin{array}{c}0.371 \\
(0.0510)\end{array}$ \\
\hline Leather Tanneries & $\begin{array}{c}0.221 \\
(0.0298)\end{array}$ & $\begin{array}{l}0.209 \\
(0.0295)\end{array}$ & $\begin{array}{c}0.236 \\
(0.0314)\end{array}$ & & & & $\begin{array}{c}0.221 \\
(0.0174)\end{array}$ \\
\hline $\begin{array}{l}\text { Wool Yarn and Cloth } \\
\text { Mills }\end{array}$ & $\begin{array}{l}0.385 \\
(0.0512)\end{array}$ & $\begin{array}{c}0.374 \\
(0.0527)\end{array}$ & $\begin{array}{c}0.378 \\
(0.0544)\end{array}$ & & & & $\begin{array}{l}0.379 \\
(0.0304)\end{array}$ \\
\hline $\begin{array}{l}\text { Veneer and Plywood } \\
\text { Míl1s }\end{array}$ & $\begin{array}{c}0.218 \\
(0.0364)\end{array}$ & $\begin{array}{l}0.211 \\
(0.0327)\end{array}$ & $\begin{array}{c}0.208 \\
(0.0329)\end{array}$ & & & & $\begin{array}{c}0.212 \\
(0.0196)\end{array}$ \\
\hline Pulp and Paper Mills & $\begin{array}{c}0.120 \\
(0.0293)\end{array}$ & $\begin{array}{c}0.120 \\
(0.0293)\end{array}$ & $\begin{array}{c}0.111 \\
(0.0276)\end{array}$ & & & & $\begin{array}{c}0.117 \\
(0.0166)\end{array}$ \\
\hline Iron Foundries & $\begin{array}{c}0.146 \\
. \quad(0.0290)\end{array}$ & $\begin{array}{l}0.147 \\
(0.0285)\end{array}$ & $\begin{array}{c}0.149 \\
(0.0286)\end{array}$ & & & & $\begin{array}{l}0.147 \\
(0.0166)\end{array}$ \\
\hline $\begin{array}{l}\text { Smelting and Refining } \\
=\end{array}$ & $\begin{array}{l}0.106 \\
(0.0280)\end{array}$ & $\begin{array}{l}0.109 \\
(0.0277)\end{array}$ & $\begin{array}{l}0.110 \\
(0.0294)\end{array}$ & & & & $\begin{array}{l}0.108 \\
(0.0164)\end{array}$ \\
\hline Boiler and Plate Works & $\begin{array}{c}0.132 \\
(0.0271)\end{array}$ & $\begin{array}{c}0.137 \\
(0.0281)\end{array}$ & $\begin{array}{c}0.133 \\
(0.0272)\end{array}$ & & ! & $\therefore *$ & $\begin{array}{l}0.134 \\
(0.0158)\end{array}$ \\
\hline $\begin{array}{l}\text { Heating Equipment } \\
\text { Manufacturers }\end{array}$ & $\begin{array}{c}0.190 \\
(0.0483)\end{array}$ & $\begin{array}{l}0.204 \\
(0.0587)\end{array}$ & $\begin{array}{c}0.201 \\
(0.0482)\end{array}$ & & & & $\begin{array}{l}0.198 \\
(0.0295)\end{array}$ \\
\hline $\begin{array}{l}\text { Office and Store Mach- } \\
\text { inery Equipt. Mnfrs. }\end{array}$ & $\begin{array}{l}0.366 \\
(0.0877)\end{array}$ & $\begin{array}{l}0.393 \\
(0.0834)\end{array}$ & $\begin{array}{c}0.443 \\
(0.0788)\end{array}$ & & & & $\begin{array}{l}0.403 \\
(0.0480)\end{array}$ \\
\hline $\begin{array}{l}\text { Motor Vehicle } \\
\text { Manufacturers }\end{array}$ & $\begin{array}{c}0.099 \\
(0.0289)\end{array}$ & $\begin{array}{l}0.106 \\
(0.0285)\end{array}$ & $\begin{array}{c}0.108 \\
(0.0287)\end{array}$ & & & & $\begin{array}{c}0.104 \\
(0.0166)\end{array}$ \\
\hline $\begin{array}{l}\text { Railroad and Rolling } \\
\text { Stock Industry }\end{array}$ & $\begin{array}{l}0.117 \\
(0.0260)\end{array}$ & $\begin{array}{c}0.120 \\
(0.0266)\end{array}$ & $\begin{array}{c}0.106 \\
(0.0286)\end{array}$ & & & & $\begin{array}{c}0.115 \\
(0.0156)\end{array}$ \\
\hline $\begin{array}{l}\text { Mnfrs. of Small Elec- } \\
\text { trical Appliances }\end{array}$ & $\begin{array}{l}0.409 \\
(0.0700)\end{array}$ & $\begin{array}{c}0.413 \\
(0.0796)\end{array}$ & $\begin{array}{c}0.415 \\
(0.0762)\end{array}$ & & & & $\begin{array}{c}0.412 \\
(0.0433)\end{array}$ \\
\hline $\begin{array}{l}\text { Mnfrs. of Major Elec- } \\
\text { trical Appliances }\end{array}$ & $\begin{array}{c}0.152 \\
(0.0294)\end{array}$ & $\begin{array}{c}0.163 \\
(0.0286)\end{array}$ & $\begin{array}{c}0.171 \\
(0.0303)\end{array}$ & & & & $\begin{array}{c}0.162 \\
(0.0170)\end{array}$ \\
\hline $\begin{array}{l}\text { Mrifrs. of H'hold Radio } \\
\text { and TV Receivers }\end{array}$ & $\begin{array}{c}0.443 \\
(0.0935)\end{array}$ & $\begin{array}{c}0.439 \\
(0.0929)\end{array}$ & $\begin{array}{c}0.433 \\
(0.0839)\end{array}$ & & & & $\begin{array}{c}0.438 \\
(0.0518)\end{array}$ \\
\hline $\begin{array}{l}\text { Clay Products } \\
\text { Manufacturers }\end{array}$ & $\begin{array}{l}0.207 \\
(0.0361)\end{array}$ & $\begin{array}{c}0.232 \\
(0.0451)\end{array}$ & $\begin{array}{c}0.241 \\
(0.0382)\end{array}$ & & & & $\begin{array}{l}0.225 \\
(0.0227)\end{array}$ \\
\hline
\end{tabular}


Table 1 (cont ${ }^{d}$.)

\begin{tabular}{|c|c|c|c|c|c|c|c|c|}
\hline $\begin{array}{l}\text { Industry } \\
(1)\end{array}$ & $\begin{array}{l}\text { Time } \\
(t)\end{array}$ & 1971 & 1972 & 1973 & 1974 & 1975 & 1976 & $\begin{array}{l}\text { Average } \\
\begin{array}{l}\text { over } \\
\text { time }\end{array} \\
\end{array}$ \\
\hline $\begin{array}{l}\text { Glass and Glass Pro- } \\
\text { ducts Manufacturers }\end{array}$ & & $\begin{array}{l}0.235 \\
(0.0385)\end{array}$ & $\begin{array}{l}0.253 \\
(0.0442)\end{array}$ & $\begin{array}{l}0.232 \\
(0.0439)\end{array}$ & & & & $\begin{array}{c}0.239 \\
(0.0242)\end{array}$ \\
\hline $\begin{array}{l}\text { Mnfrs. of Pharmaceut- } \\
\text { icals and Medicines }\end{array}$ & & $\begin{array}{c}0.483 \\
(0.0921)\end{array}$ & $\begin{array}{c}0.472 \\
(0.0865)\end{array}$ & $\begin{array}{l}0.473 \\
(0.0850)\end{array}$ & & & & $\begin{array}{c}0.476^{2} \\
(0.0506)\end{array}$ \\
\hline $\begin{array}{l}\text { Paint and Varnish } \\
\text { Manufacturers }\end{array}$ & & $\begin{array}{l}0.206 \\
(0.0699)\end{array}$ & $\begin{array}{l}0.189 \\
(0.0612)\end{array}$ & $\begin{array}{l}0.189 \\
(0.0610)\end{array}$ & & & & $\begin{array}{l}0.194 \\
(0.0368)\end{array}$ \\
\hline $\begin{array}{l}\text { Industry } \\
\text { Average }\end{array}$ & & $\begin{array}{c}0.177 \\
(0.0106)\end{array}$ & $\begin{array}{l}0.175 \\
(0.0105)\end{array}$ & $\begin{array}{l}0.174 \\
(0.0105)\end{array}$ & $\begin{array}{l}0.187 \\
(0.0202)\end{array}$ & $\begin{array}{c}0.191 \\
(0.0200)\end{array}$ & $\begin{array}{c}0.193 \\
(0.0203)\end{array}$ & $\begin{array}{l}0.180 \\
(0.0023)\end{array}$ \\
\hline
\end{tabular}

Grand Average 
Table 2

\begin{tabular}{|c|c|c|c|c|c|c|c|c|}
\hline $\begin{array}{l}\text { Industry } \\
\text { (i) }\end{array}$ & $\begin{array}{c}\text { Time } \\
(t)\end{array}$ & 1971 & 1972 & 1973 & 1974 & 1975 & 1976 & $\begin{array}{c}\text { Average } \\
\text { over } \\
\text { time } \\
\end{array}$ \\
\hline $\begin{array}{l}\text { Slaughtering and Meat } \\
\text { Processors }\end{array}$ & & $\begin{array}{l}0.191 \\
(0.0331)\end{array}$ & $\begin{array}{l}0.190 \\
(0.0328)\end{array}$ & $\begin{array}{l}0.190 \\
(0.0317)\end{array}$ & $\begin{array}{l}0.190 \\
(0.0319)\end{array}$ & $\begin{array}{l}0.190 \\
(0.0323)\end{array}$ & $\begin{array}{l}0.188 \\
(0.0325)\end{array}$ & $\begin{array}{l}0.190 \\
(0.0132)\end{array}$ \\
\hline $\begin{array}{l}\text { Fish Products } \\
\text { Industries }\end{array}$ & & $\begin{array}{l}0.248 \\
(0.0483)\end{array}$ & $\begin{array}{l}0.254 \\
(0.0495)\end{array}$ & $\begin{array}{l}0.259 \\
(0.0495)\end{array}$ & $\begin{array}{l}0.260 \\
(0.0507)\end{array}$ & $\begin{array}{l}0.259 \\
(0.0526)\end{array}$ & $\begin{array}{l}0.266 \\
(0.0541)\end{array}$ & $\begin{array}{l}0.257 \\
(0.0207)\end{array}$ \\
\hline $\begin{array}{l}\text { Dairy Products } \\
\text { Industries }\end{array}$ & & $\begin{array}{l}0.178 \\
(0.0375)\end{array}$ & $\begin{array}{l}0.176 \\
(0.0335)\end{array}$ & $\begin{array}{l}0.178 \\
(0.0333)\end{array}$ & $\begin{array}{l}0.177 \\
(0.0333)\end{array}$ & $\begin{array}{l}0.175 \\
(0.0312)\end{array}$ & $\begin{array}{l}0.178 \\
(0.0326)\end{array}$ & $\begin{array}{l}0.177 \\
(0.0136)\end{array}$ \\
\hline $\begin{array}{l}\text { Grain Mill Products } \\
\text { Industries }\end{array}$ & & $\begin{array}{l}0.171 \\
(0.0337)\end{array}$ & $\begin{array}{l}0.175 \\
(0.0398)\end{array}$ & $\begin{array}{l}0.171 \\
(0.0336)\end{array}$ & $\begin{array}{l}0.172 \\
(0.0351)\end{array}$ & $\begin{array}{l}0.173 \\
(0.0334)\end{array}$ & $\begin{array}{l}0.173 \\
(0.0320)\end{array}$ & $\begin{array}{l}0.172 \\
(0.0140)\end{array}$ \\
\hline $\begin{array}{l}\text { Bakery Products } \\
\text { Industries }\end{array}$ & & $\begin{array}{l}0.244 \\
(0.0479)\end{array}$ & $\begin{array}{l}0.242 \\
(0.0470)\end{array}$ & $\begin{array}{l}0.240 \\
(0.0466)\end{array}$ & $\begin{array}{l}0.240 \\
(0.0482)\end{array}$ & $\begin{array}{l}0.238 \\
(0.0440)\end{array}$ & $\begin{array}{l}0.234 \\
(0.0438)\end{array}$ & $\begin{array}{c}0.0239 \\
(0.0188)\end{array}$ \\
\hline $\begin{array}{l}\text { Soft Drink } \\
\text { Manufacturers }\end{array}$ & & $\begin{array}{l}0.177 \\
(0.0484)\end{array}$ & $\begin{array}{l}0.175 \\
(0.0469)\end{array}$ & $\begin{array}{l}0.174 \\
(0.0440)\end{array}$ & $\begin{array}{l}0.174 \\
(0.0397)\end{array}$ & $\begin{array}{l}0.175 \\
(0.0423)\end{array}$ & $\begin{array}{l}0.173 \\
(0.0411)\end{array}$ & $\begin{array}{l}0.175 \\
(0.0177)\end{array}$ \\
\hline Breweries & & $\begin{array}{l}0.141 \\
(0.0268)\end{array}$ & $\begin{array}{l}0.140 \\
(0.0273)\end{array}$ & $\begin{array}{l}0.139 \\
(0.0267)\end{array}$ & $\begin{array}{l}0.138 \\
(0.0263)\end{array}$ & $\begin{array}{l}0.139 \\
(0.0250)\end{array}$ & $\begin{array}{l}0.138 \\
(0.0255)\end{array}$ & $\begin{array}{c}0.139 \\
(0.0107)\end{array}$ \\
\hline Shoe Factories & - & $\begin{array}{l}0.326 \\
(0.0715)\end{array}$ & $\begin{array}{l}0.325 \\
(0.0705)\end{array}$ & $\begin{array}{l}0.330 \\
(0.0724)\end{array}$ & $\begin{array}{l}0.333 \\
(0.0724)\end{array}$ & $\begin{array}{l}0.331 \\
(0.0737)\end{array}$ & $\begin{array}{l}0.329 \\
(0.0710)\end{array}$ & $\begin{array}{l}0.329 \\
(0.0294)\end{array}$ \\
\hline $\begin{array}{l}\text { Hoisery and Knitting } \\
=\text { Mills }\end{array}$ & & $\begin{array}{l}0.353 \\
(0.0815)\end{array}$ & $\begin{array}{l}0.350 \\
(0.0782)\end{array}$ & $\begin{array}{l}0.349 \\
(0.0800)\end{array}$ & $\begin{array}{l}0.349 \\
(0.0800)\end{array}$ & $\begin{array}{l}0.354 \\
(0.0801)\end{array}$ & $\begin{array}{l}0.356 \\
(0.0807)\end{array}$ & $\begin{array}{l}0.352 \\
(0.0327)\end{array}$ \\
\hline $\begin{array}{l}\text { Men's clothing } \\
\text { Industries }\end{array}$ & & $\begin{array}{l}0.368 \\
(0.0813)\end{array}$ & $\begin{array}{l}0.372 \\
(0.0829)\end{array}$ & $\begin{array}{l}0.375 \\
(0.0833)\end{array}$ & $\begin{array}{l}0.377 \\
(0.0833)\end{array}$ & $\begin{array}{l}0.371 \\
(0.0820)\end{array}$ & $\begin{array}{l}0.371 \\
(0.0819)\end{array}$ & $\begin{array}{l}0.372 \\
(0.0337)\end{array}$ \\
\hline $\begin{array}{l}\text { Women's Clothing } \\
\text { Industries }\end{array}$ & & $\begin{array}{l}0.394 \\
(0.0884)\end{array}$ & $\begin{array}{l}0.393 \\
(0.0881)\end{array}$ & $\begin{array}{l}0.393 \\
(0.0883)\end{array}$ & $\begin{array}{l}0.394 \\
(0.0882)\end{array}$ & $\begin{array}{l}0.391 \\
(0.0884)\end{array}$ & $\begin{array}{c}0.387 \\
(0.0867)\end{array}$ & $\begin{array}{l}0.392 \\
(0.0360)\end{array}$ \\
\hline $\begin{array}{l}\text { Children's Clothing } \\
\text { Industries }\end{array}$ & & $\begin{array}{l}0.399 \\
(0.0955)\end{array}$ & $\begin{array}{l}0.405 \\
(0.1002)\end{array}$ & $\begin{array}{l}0.402 \\
(0.0981)\end{array}$ & $\begin{array}{l}0.404 \\
(0.1005)\end{array}$ & $\begin{array}{l}0.401 \\
(0.0945)\end{array}$ & $\begin{array}{l}0.405 \\
(0.0949)\end{array}$ & $\begin{array}{l}0.402 \\
(0.0397)\end{array}$ \\
\hline $\begin{array}{l}\text { Saw Mills, Planing Mills } \\
\text { and Shingle Mills }\end{array}$ & & $\begin{array}{l}0.153 \\
(0.0303)\end{array}$ & $\begin{array}{l}0.154 \\
(0.0298)\end{array}$ & $\begin{array}{l}0.153 \\
(0.0280)\end{array}$ & $\begin{array}{l}0.153 \\
(0.0279)\end{array}$ & $\begin{array}{l}0.154 \\
(0.0294)\end{array}$ & $\begin{array}{l}0.155 \\
(0.0280)\end{array}$ & $\begin{array}{l}0.154 \\
(0.0118)\end{array}$ \\
\hline $\begin{array}{l}\text { Household Office and } \\
\text { Other Furniture Mnfs. }\end{array}$ & & $\begin{array}{l}0.194 \\
(0.0394)\end{array}$ & $\begin{array}{l}0.198 \\
(0.0406)\end{array}$ & $\begin{array}{l}0.202 \\
(0.0416)\end{array}$ & $\begin{array}{l}0.206 \\
(0.0410)\end{array}$ & $\begin{array}{l}0.206 \\
(0.0404)\end{array}$ & $\begin{array}{l}0.210 \\
(0.0418)\end{array}$ & $\begin{array}{l}0.202 \\
(0.0166)\end{array}$ \\
\hline $\begin{array}{l}\text { Paper Box and Bag } \\
\text { Manufacturers }\end{array}$ & & $\begin{array}{l}0.211 \\
(0.0373)\end{array}$ & $\begin{array}{l}0.211 \\
(0.0375)\end{array}$ & $\begin{array}{l}0.211 \\
(0.0374)\end{array}$ & $\begin{array}{l}0.210 \\
(0.0368)\end{array}$ & $\begin{array}{l}0.213 \\
(0.0376)\end{array}$ & $\begin{array}{l}0.209 \\
(0.0368)\end{array}$ & $\begin{array}{l}0.211 \\
(0.0152)\end{array}$ \\
\hline Iron and Steel Mills & & $\begin{array}{l}0.151 \\
(0.0258)\end{array}$ & $\begin{array}{l}0.151 \\
(0.0254)\end{array}$ & $\begin{array}{l}0.151 \\
(0.0253)\end{array}$ & $\begin{array}{l}0.150 \\
(0.0249)\end{array}$ & $\begin{array}{l}0.155 \\
(0.0283)\end{array}$ & $\begin{array}{l}0.154 \\
(0.0263)\end{array}$ & $\begin{array}{l}0.152 \\
(0.0106)\end{array}$ \\
\hline $\begin{array}{l}\text { Fabricated Structural } \\
\text { Metal Industry }\end{array}$ & & $\begin{array}{l}0.143 \\
(0.0231)\end{array}$ & $\begin{array}{l}0.147 \\
(0.0243)\end{array}$ & $\begin{array}{l}0.144 \\
(0.0225)\end{array}$ & $\begin{array}{l}0.143 \\
(0.0219)\end{array}$ & $\begin{array}{l}0.145 \\
(0.0224)\end{array}$ & $\begin{array}{l}0.142 \\
(0.0237)\end{array}$ & $\begin{array}{l}0.144 \\
(0.0094)\end{array}$ \\
\hline $\begin{array}{l}\text { Ornamental and Archi- } \\
\text { tectural Metal Ind. }\end{array}$ & & $\begin{array}{l}0.172 \\
(0.0337)\end{array}$ & $\begin{array}{l}0.174 \\
(0.0342)\end{array}$ & $\begin{array}{l}0.181 \\
(0.0379)\end{array}$ & $\begin{array}{l}0.176 \\
(0.0339)\end{array}$ & $\begin{array}{l}0.173 \\
(0.0298)\end{array}$ & $\begin{array}{c}0.173 \\
(0.0306)\end{array}$ & $\begin{array}{l}0.175 \\
(0.0135)\end{array}$ \\
\hline
\end{tabular}


Table 2 (cont'd.)

\begin{tabular}{|c|c|c|c|c|c|c|c|c|}
\hline $\begin{array}{l}\text { Industry } \\
\text { (i) }\end{array}$ & $\begin{array}{l}\text { Time } \\
(t)\end{array}$ & 1971 & 1972 & 1973 & 1974 & 1975 & 1976 & $\begin{array}{l}\text { Average } \\
\text { over } \\
\text { time } \\
\end{array}$ \\
\hline $\begin{array}{l}\text { Metal Stamping, Process } \\
\text { and Coating Industry }\end{array}$ & & $\begin{array}{l}0.184 \\
(0.0334)\end{array}$ & $\begin{array}{l}0.185 \\
(0.0328)\end{array}$ & $\begin{array}{l}0.185 \\
(0.0329)\end{array}$ & $\begin{array}{l}0.188 \\
(0.0341)\end{array}$ & $\begin{array}{l}0.187 \\
(0.0325)\end{array}$ & $\begin{array}{l}0.188 \\
(0.0328)\end{array}$ & $\begin{array}{l}0.186 \\
(0.0135)\end{array}$ \\
\hline $\begin{array}{l}\text { Wire and Wire Products } \\
\text { Manufacturers }\end{array}$ & & $\begin{array}{l}0.183 \\
(0.0307)\end{array}$ & $\begin{array}{l}0.183 \\
(0.0305)\end{array}$ & $\begin{array}{l}0.181 \\
(0.0297)\end{array}$ & $\begin{array}{l}0.179 \\
(0.0289)\end{array}$ & $\begin{array}{l}0.176 \\
(0.0289)\end{array}$ & $\begin{array}{l}0.181 \\
(0.0299)\end{array}$ & $\begin{array}{l}0.180 \\
(0.0121)\end{array}$ \\
\hline Machine Shops & & $\begin{array}{l}0.174 \\
(0.0564)\end{array}$ & $\begin{array}{l}0.168 \\
(0.0488)\end{array}$ & $\begin{array}{l}0.171 \\
(0.0514)\end{array}$ & $\begin{array}{l}0.171 \\
(0.0474)\end{array}$ & $\begin{array}{l}0.176 \\
(0.0526)\end{array}$ & $\begin{array}{l}0.177 \\
(0.0552)\end{array}$ & $\begin{array}{l}0.173 \\
(0.0211)\end{array}$ \\
\hline $\begin{array}{l}\text { Agricultural Implement } \\
\text { Industry }\end{array}$ & & $\begin{array}{l}0.145 \\
(0.0238)\end{array}$ & $\begin{array}{l}0.146 \\
(0.0235)\end{array}$ & $\begin{array}{l}0.150 \\
(0.0270)\end{array}$ & $\begin{array}{l}0.146 \\
(0.0239)\end{array}$ & $\begin{array}{l}0.147 \\
(0.0246)\end{array}$ & $\begin{array}{l}0.145 \\
(0.0267)\end{array}$ & $\begin{array}{l}0.146 \\
(0.0101)\end{array}$ \\
\hline $\begin{array}{l}\text { Misc. Machinery and Equi } \\
\text { ment Manufacturers }\end{array}$ & & $\begin{array}{l}0.161 \\
(0.0263)\end{array}$ & $\begin{array}{l}0.162 \\
(0.0271)\end{array}$ & $\begin{array}{l}0.160 \\
(0.0258)\end{array}$ & $\begin{array}{l}0.159 \\
(0.0249)\end{array}$ & $\begin{array}{l}0.159 \\
(0.0247)\end{array}$ & $\begin{array}{l}0.161 \\
(0.0252)\end{array}$ & $\begin{array}{l}0.160 \\
(0.0105)\end{array}$ \\
\hline $\begin{array}{l}\text { Aircraft and Aircraft } \\
\text { Parts Manufacturers }\end{array}$ & & $\begin{array}{l}0.151 \\
(0.0245)\end{array}$ & $\begin{array}{l}0.152 \\
(0.0246)\end{array}$ & $\begin{array}{l}0.154 \\
(0.0244)\end{array}$ & $\begin{array}{l}0.162 \\
(0.0256)\end{array}$ & $\begin{array}{l}0.162 \\
(0.0254)\end{array}$ & $\begin{array}{l}0.160 \\
(0.0252)\end{array}$ & $\begin{array}{l}0.157 \\
(0.0102)\end{array}$ \\
\hline $\begin{array}{c}\text { Motor Vehicle Parts and } \\
\text { Accessories Mnfrs. }\end{array}$ & & $\begin{array}{l}0.191 \\
(0.0338)\end{array}$ & $\begin{array}{l}0.195 \\
(0.0339)\end{array}$ & $\begin{array}{l}0.196 \\
(0.0353)\end{array}$ & $\begin{array}{l}0.196 \\
(0.0353)\end{array}$ & $\begin{array}{l}0.187 \\
(0.0321)\end{array}$ & $\begin{array}{l}0.190 \\
(0.0329)\end{array}$ & $\begin{array}{l}0.192 \\
(0.0138)\end{array}$ \\
\hline Shipbuilding and Repair & & $\begin{array}{l}0.140 \\
(0.0296)\end{array}$ & $\begin{array}{l}0.141 \\
(0.0305)\end{array}$ & $\begin{array}{l}0.140 \\
(0.0322)\end{array}$ & $\begin{array}{l}0.141 \\
(0.0286)\end{array}$ & $\begin{array}{l}0.141 \\
(0.0305)\end{array}$ & $\begin{array}{l}0.141 \\
(0.0314)\end{array}$ & $\begin{array}{l}0.141 \\
(0.0124)\end{array}$ \\
\hline $\begin{array}{l}\text { Communications Equip- } \\
\text {, ment Manufacturers }\end{array}$ & & $\begin{array}{l}0.295 \\
(0.0584)\end{array}$ & $\begin{array}{l}0.296 \\
(0.0579)\end{array}$ & $\begin{array}{l}0.305 \\
(0.0600)\end{array}$ & $\begin{array}{l}0.301 \\
(0.0590)\end{array}$ & $\begin{array}{l}0.285 \\
(0.0550)\end{array}$ & $\begin{array}{l}0.289 \\
(0.0559)\end{array}$ & $\begin{array}{l}0.295 \\
(0.0235)\end{array}$ \\
\hline $\begin{array}{l}\text { Mnfrs. of Electrical } \\
\text { Industrial Equipt. }\end{array}$ & & $\begin{array}{l}0.209 \\
(0.0361)\end{array}$ & $\begin{array}{l}0.213 \\
(0.0378)\end{array}$ & $\begin{array}{l}0.222 \\
(0.0394)\end{array}$ & $\begin{array}{l}0.213 \\
(0.0381)\end{array}$ & $\begin{array}{l}0.205 \\
(0.0362)\end{array}$ & $\begin{array}{l}0.213 \\
(0.0379)\end{array}$ & $\begin{array}{l}0.212 \\
(0.0153)\end{array}$ \\
\hline Petroleum Refineries & & $\begin{array}{l}0.143 \\
(0.0268)\end{array}$ & $\begin{array}{l}0.144 \\
(0.0268)\end{array}$ & $\begin{array}{l}0.143 \\
(0.0275)\end{array}$ & $\begin{array}{l}0.144 \\
(0.0299)\end{array}$ & $\begin{array}{l}0.153 \\
(0.0351)\end{array}$ & $\begin{array}{l}0.156 \\
(0.0390)\end{array}$ & $\begin{array}{l}0.146 \\
(0.0122)\end{array}$ \\
\hline $\begin{array}{l}\text { Mnfrs. of Industrial } \\
\text { Chemicals }\end{array}$ & & $\begin{array}{l}0.146 \\
(0.0233)\end{array}$ & $\begin{array}{l}0.146 \\
(0.0232)\end{array}$ & $\begin{array}{l}0.147 \\
(0.0247)\end{array}$ & $\begin{array}{l}0.146 \\
(0.0264)\end{array}$ & $\begin{array}{l}0.145 \\
(0.0255)\end{array}$ & $\begin{array}{l}0.147 \\
(0.0253)\end{array}$ & $\begin{array}{l}0.146 \\
(0.0101)\end{array}$ \\
\hline Logging Eastern Canada & & $\begin{array}{l}0.152 \\
(0.0301)\end{array}$ & $\begin{array}{l}0.150 \\
(0.0288)\end{array}$ & $\begin{array}{l}0.151 \\
(0.0265)\end{array}$ & & & & $\begin{array}{l}0.151 \\
(0.0164)\end{array}$ \\
\hline Logging British Columbia & & $\begin{array}{l}0.148 \\
(0.0232)\end{array}$ & $\begin{array}{l}0.147 \\
(0.0223)\end{array}$ & $\begin{array}{l}0.145 \\
(0.0242)\end{array}$ & & & & $\begin{array}{l}0.147 \\
(0.0134)\end{array}$ \\
\hline Gold-Quartz Mining & & $\begin{array}{c}0.147 \\
(0.0267)\end{array}$ & $\begin{array}{l}0.147 \\
(0.0232)\end{array}$ & $\begin{array}{l}0.146 \\
(0.0225)\end{array}$ & & & & $\begin{array}{l}0.146 \\
(0.0138)\end{array}$ \\
\hline Iron & & $\begin{array}{c}0.137 \\
(0.0264)\end{array}$ & $\begin{array}{c}0.139 \\
(0.0244)\end{array}$ & $\begin{array}{c}0.138 \\
(0.0243)\end{array}$ & & & & $\begin{array}{c}0.138 \\
(0.0144)\end{array}$ \\
\hline Other Metals & & $\begin{array}{l}0.140 \\
(0.0233)\end{array}$ & $\begin{array}{c}0.140 \\
(0.0234)\end{array}$ & $\begin{array}{c}0.142 \\
(0.0267)\end{array}$ & & & & $\begin{array}{c}0.140 \\
(0.0140)\end{array}$ \\
\hline Coal & & $\begin{array}{c}0.169 \\
(0.0560)\end{array}$ & $\begin{array}{c}0.140 \\
(0.0241)\end{array}$ & $\begin{array}{c}0.141 \\
(0.0221)\end{array}$ & & & & $\begin{array}{l}0.143 \\
(0.0156\end{array}$ \\
\hline
\end{tabular}


Table 2 (cont'd.)

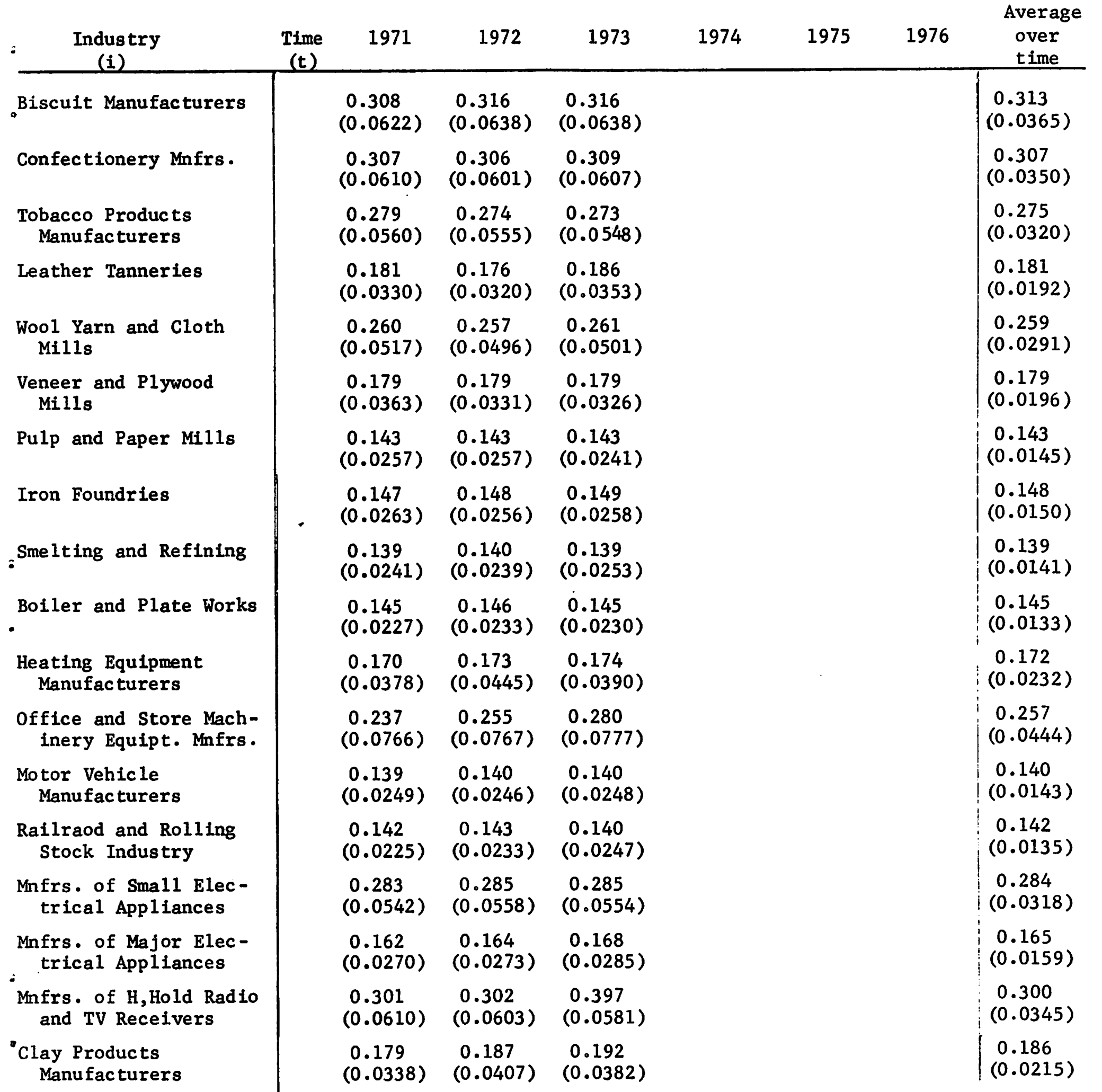


Table 2 (cont'd.)

\begin{tabular}{|c|c|c|c|c|c|c|c|c|}
\hline $\begin{array}{c}\text { Industry } \\
(i)\end{array}$ & $\begin{array}{c}\text { Time } \\
(t)\end{array}$ & 1971 & 1972 & 1973 & 1974 & 1975 & 1976 & $\begin{array}{c}\begin{array}{c}\text { Average } \\
\text { over } \\
\text { time }\end{array} \\
\end{array}$ \\
\hline $\begin{array}{l}\text { Glass and Glass Pro- } \\
\text { ducts Manufacturers }\end{array}$ & & $\begin{array}{l}0.199 \\
(0.0346)\end{array}$ & $\begin{array}{l}0.208 \\
(0.0373)\end{array}$ & $\begin{array}{l}0.199 \\
(0.0362)\end{array}$ & & & & $\begin{array}{c}= \\
0.202 \\
(0.0208)\end{array}$ \\
\hline $\begin{array}{l}\text { Mnfrs. of Pharmaceut- } \\
\text { icals and Medicines }\end{array}$ & & $\begin{array}{l}0.315 \\
(0.0859)\end{array}$ & $\begin{array}{l}0.311 \\
(0.0807)\end{array}$ & $\begin{array}{l}0.311 \\
(0.0795)\end{array}$ & & & & $\begin{array}{l}0.312= \\
(0.0473)\end{array}$ \\
\hline $\begin{array}{l}\text { Paint and Varnish } \\
\text { Manufacturers }\end{array}$ & & $\begin{array}{l}0.185 \\
(0.0543)\end{array}$ & $\begin{array}{l}0.179 \\
(0.0481)\end{array}$ & $\begin{array}{l}0.179 \\
(0.0479)\end{array}$ & & & & $\begin{array}{c}0.181 \\
(0.0288) \\
\end{array}$ \\
\hline $\begin{array}{l}\text { Industry } \\
\text { Average }\end{array}$ & & $\begin{array}{c}0.167 \\
(0.0094)\end{array}$ & $\begin{array}{c}0.167 \\
(0.0092)\end{array}$ & $\begin{array}{c}0.168 \\
(0.0092)\end{array}$ & $\begin{array}{c}0.173 \\
(0.0181)\end{array}$ & $\begin{array}{c}0.174 \\
(0.0182)\end{array}$ & $\begin{array}{c}0.175 \\
(0.0184)\end{array}$ & $\begin{array}{l}0.170 \\
(0.0020)\end{array}$ \\
\hline
\end{tabular}


Table 3

$\phi_{3 \text { it }}$

\begin{tabular}{|c|c|c|c|c|c|c|c|}
\hline $\begin{array}{l}\text { Industry } \\
\text { (i) }\end{array}$ & $\begin{array}{l}\text { Time } \\
(t)\end{array}$ & 1972 & 1973 & 1974 & 1975 & 1976 & $\begin{array}{c}\text { Average } \\
\text { over } \\
\text { time } \\
\end{array}$ \\
\hline $\begin{array}{l}\text { Slaughtering and Meat } \\
\text { Processors }\end{array}$ & $\begin{array}{l}0.190 \\
(0.0214)\end{array}$ & $\begin{array}{l}0.186 \\
(0.0214)\end{array}$ & $\begin{array}{l}0.194 \\
(0.0212)\end{array}$ & $\begin{array}{l}0.187 \\
(0.0216)\end{array}$ & $\begin{array}{l}0.187 \\
(0.0215)\end{array}$ & $\begin{array}{l}0.177 \\
(0.0218)\end{array}$ & $\begin{array}{l}0.187 \\
(0.0088)\end{array}$ \\
\hline $\begin{array}{c}\text { Fish Products, } \\
\text { Industries }\end{array}$ & $\begin{array}{l}0.279 \\
(0.0302)\end{array}$ & $\begin{array}{l}0.281 \\
(0.0311)\end{array}$ & $\begin{array}{l}0.279 \\
(0.0321)\end{array}$ & $\begin{array}{l}0.269 \\
(0.0318)\end{array}$ & $\begin{array}{l}0.263 \\
(0.0321)\end{array}$ & $\begin{array}{l}0.273 \\
(0.0334)\end{array}$ & $\begin{array}{c}0.274 \\
(0.0130)\end{array}$ \\
\hline $\begin{array}{l}\text { Dairy Products, } \\
\text { Industries }\end{array}$ & $\begin{array}{l}0.244 \\
(0.0262)\end{array}$ & $\begin{array}{l}0.224 \\
(0.0237)\end{array}$ & $\begin{array}{l}0.223 \\
(0.0236)\end{array}$ & $\begin{array}{l}0.222 \\
(0.0237)\end{array}$ & $\begin{array}{l}0.210 \\
(0.0225)\end{array}$ & $\begin{array}{l}0.220 \\
(0.0231)\end{array}$ & $\begin{array}{l}0.223 \\
(0.0097)\end{array}$ \\
\hline $\begin{array}{l}\text { Grain Mill Products } \\
\text { Industries }\end{array}$ & $\begin{array}{l}0.229 \\
(0.0239)\end{array}$ & $\begin{array}{l}0.255 \\
(0.0277)\end{array}$ & $\begin{array}{l}0.226 \\
(0.0240)\end{array}$ & $\begin{array}{l}0.232 \\
(0.0249)\end{array}$ & $\begin{array}{l}0.225 \\
(0.0239)\end{array}$ & $\begin{array}{l}0.217 \\
(0.0231)\end{array}$ & $\begin{array}{l}0.229 \\
(0.0100)\end{array}$ \\
\hline $\begin{array}{l}\text { Bakery Products } \\
\text { Industries }\end{array}$ & $\begin{array}{l}0.289 \\
(0.0307)\end{array}$ & $\begin{array}{l}0.283 \\
(0.0299)\end{array}$ & $\begin{array}{l}0.284 \\
(0.0300)\end{array}$ & $\begin{array}{l}0.295 \\
(0.0313)\end{array}$ & $\begin{array}{l}0.256 \\
(0.0279)\end{array}$ & $\begin{array}{l}0.262 \\
(0.0276)\end{array}$ & $\begin{array}{c}0.0277 \\
(0.0120)\end{array}$ \\
\hline $\begin{array}{l}\text { Soft Drink Manu- } \\
\text { facturing }\end{array}$ & $\begin{array}{l}0.280 \\
(0.0336)\end{array}$ & $\begin{array}{c}0.274 \\
(0.0326)\end{array}$ & $\begin{array}{l}0.262 \\
(0.0308)\end{array}$ & $\begin{array}{l}0.247 \\
(0.0280)\end{array}$ & $\begin{array}{c}0.257 \\
(0.0296)\end{array}$ & $\begin{array}{c}0.256 \\
(0.0288)\end{array}$ & $\begin{array}{c}0.261 \\
(0.0124)\end{array}$ \\
\hline Breweries & $\begin{array}{c}0.134 \\
(0.0254)\end{array}$ & $\begin{array}{c}0.128 \\
(0.0260)\end{array}$ & $\begin{array}{l}0.125 \\
(0.0258)\end{array}$ & $\begin{array}{l}0.119 \\
(0.0257)\end{array}$ & $\begin{array}{c}0.125 \\
(0.0245)\end{array}$ & $\begin{array}{l}0.116 \\
(0.0251)\end{array}$ & $\begin{array}{c}0.124 \\
(0.0104)\end{array}$ \\
\hline Shoe Factories & $\begin{array}{l}0.365 \\
(0.0477)\end{array}$ & $\begin{array}{c}0.351 \\
(0.0469)\end{array}$ & $\begin{array}{l}0.370 \\
(0.0488)\end{array}$ & $\begin{array}{c}0.362 \\
(0.0488)\end{array}$ & $\begin{array}{l}0.379 \\
(0.0496)\end{array}$ & $\begin{array}{l}0.354 \\
(0.0476)\end{array}$ & $\begin{array}{c}0.363 \\
(0.0197)\end{array}$ \\
\hline $\begin{array}{l}\text { Ḣosiery and Knitting } \\
\text { Mills }\end{array}$ & $\begin{array}{c}0.431 \\
(0.0574)\end{array}$ & $\begin{array}{l}0.407 \\
(0.0546)\end{array}$ & $\begin{array}{l}0.423 \\
(0.0560)\end{array}$ & $\begin{array}{l}0.423 \\
(0.0559)\end{array}$ & $\begin{array}{l}0.413 \\
(0.0558)\end{array}$ & $\begin{array}{l}0.412 \\
(0.0560)\end{array}$ & $\begin{array}{l}0.418 \\
(0.0228)\end{array}$ \\
\hline $\begin{array}{l}\text { Men's Clothing } \\
\text { Industries }\end{array}$ & $\begin{array}{c}0.380 \\
(0.0563)\end{array}$ & $\begin{array}{l}0.391 \\
(0.0577)\end{array}$ & $\begin{array}{l}0.390 \\
(0.0582)\end{array}$ & $\begin{array}{l}0.384 \\
(0.0583)\end{array}$ & $\begin{array}{l}0.366 \\
(0.0567)\end{array}$ & $\begin{array}{l}0.366 \\
(0.0567)\end{array}$ & $\begin{array}{l}0.379 \\
(0.0234)\end{array}$ \\
\hline $\begin{array}{l}\text { Women's clothing } \\
\text { Industries }\end{array}$ & $\begin{array}{l}0.419 \\
(0.0631)\end{array}$ & $\begin{array}{l}0.416 \\
(0.0628)\end{array}$ & $\begin{array}{l}0.419 \\
(0.0630)\end{array}$ & $\begin{array}{c}0.419 \\
(0.0632)\end{array}$ & $\begin{array}{l}0.425 \\
(0.0629)\end{array}$ & $\begin{array}{l}0.414 \\
(0.0614)\end{array}$ & $\begin{array}{l}0.419 \\
(0.0256)\end{array}$ \\
\hline $\begin{array}{l}\text { Children's clothing } \\
\text { Industries }\end{array}$ & $\begin{array}{l}0.486 \\
(0.0690)\end{array}$ & $\begin{array}{c}0.511 \\
(0.0727)\end{array}$ & $\begin{array}{l}0.501 \\
(0.0711)\end{array}$ & $\begin{array}{l}0.516 \\
(0.0731)\end{array}$ & $\begin{array}{c}0.477 \\
(0.0684)\end{array}$ & $\begin{array}{c}0.474 \\
(0.0688)\end{array}$ & $\begin{array}{l}0.493 \\
(0.0288)\end{array}$ \\
\hline $\begin{array}{l}\text { Saw Mills, Planing Mills } \\
\text { and Shingle Mills }\end{array}$ & $\begin{array}{l}0.206 \\
(0.0239)\end{array}$ & $\begin{array}{l}0.215 \\
(0.0231)\end{array}$ & $\begin{array}{l}0.206 \\
(0.0219)\end{array}$ & $\begin{array}{l}0.196 \\
(0.0222)\end{array}$ & $\begin{array}{l}0.197 \\
(0.0231)\end{array}$ & $\begin{array}{l}0.194 \\
(0.0220)\end{array}$ & $\begin{array}{l}0.202 \\
(0.0093)\end{array}$ \\
\hline $\begin{array}{l}\text { Household Office and } \\
\text { Other Furniture Mnfs. }\end{array}$ & $\begin{array}{l}0.258 \\
(0.0256)\end{array}$ & $\begin{array}{l}0.264 \\
(0.0262)\end{array}$ & $\begin{array}{c}0.269 \\
(0.0268)\end{array}$ & $\begin{array}{c}0.263 \\
(0.0260)\end{array}$ & $\begin{array}{l}0.256 \\
(0.0253)\end{array}$ & $\begin{array}{l}0.261 \\
(0.0261)\end{array}$ & $\begin{array}{l}0.262 \\
(0.0106)\end{array}$ \\
\hline $\begin{array}{l}\text { Papel Box and Bag } \\
\text { Manufacturers }\end{array}$ & $\begin{array}{l}0.214 \\
(0.0234)\end{array}$ & $\begin{array}{c}0.217 \\
(0.0233)\end{array}$ & $\begin{array}{l}0.222 \\
(0.0232)\end{array}$ & $\begin{array}{l}0.227 \\
(0.0234)\end{array}$ & $\begin{array}{l}0.226 \\
(0.0235)\end{array}$ & $\begin{array}{l}0.215 \\
(0.0230)\end{array}$ & $\begin{array}{l}0.220 \\
(0.0095)\end{array}$ \\
\hline Iron and Steel Mills & $\begin{array}{l}0.194 \\
(0.0209)\end{array}$ & $\begin{array}{l}0.192 \\
(0.0208)\end{array}$ & $\begin{array}{c}0.191 \\
(0.0207)\end{array}$ & $\begin{array}{c}0.188 \\
(0.0206)\end{array}$ & $\begin{array}{l}0.208 \\
(0.0219)\end{array}$ & $\begin{array}{c}0.196 \\
(0.0209)\end{array}$ & $\begin{array}{l}0.195 \\
(0.0086)\end{array}$ \\
\hline $\begin{array}{l}\text { Fabricated Structural } \\
\text { - Metal Industry }\end{array}$ & $\begin{array}{l}0.147 \\
(0.0211)\end{array}$ & $\begin{array}{c}0.171 \\
(0.0209)\end{array}$ & $\begin{array}{c}0.150 \\
(0.0208)\end{array}$ & $\begin{array}{l}0.146 \\
(0.0207)\end{array}$ & $\begin{array}{c}0.145 \\
(0.0208)\end{array}$ & $\begin{array}{c}0.133 \\
(0.0220)\end{array}$ & $\begin{array}{l}0.149 \\
(0.0086)\end{array}$ \\
\hline $\begin{array}{l}\text { Ornamental and Archi- } \\
\text { tectural Metal Ind. }\end{array}$ & $\begin{array}{c}0.235 \\
(0.0236)\end{array}$ & $\begin{array}{c}0.237 \\
(0.0236)\end{array}$ & $\begin{array}{c}0.254 \\
(0.0257)\end{array}$ & $\begin{array}{c}0.235 \\
(0.0233)\end{array}$ & $\begin{array}{l}0.212 \\
(0.0209)\end{array}$ & $\begin{array}{c}0.217 \\
(0.0214)\end{array}$ & $\begin{array}{l}0.230 \\
(0.0093)\end{array}$ \\
\hline
\end{tabular}


Table 3 (cont'd)

\begin{tabular}{|c|c|c|c|c|c|c|c|c|}
\hline $\begin{array}{l}\text { Industry } \\
\text { (i) }\end{array}$ & $\begin{array}{l}\text { Time } \\
(t)\end{array}$ & 1971 & 1972 & 1973 & 1974 & 1975 & 1976 & $\begin{array}{l}\text { Average } \\
\text { over } \\
\text { time }\end{array}$ \\
\hline $\begin{array}{l}\text { Metal Stamping, Process } \\
\text { and Coating Industry }\end{array}$ & & $\begin{array}{l}0.230 \\
(0.0222)\end{array}$ & $\begin{array}{l}0.225 \\
(0.0218)\end{array}$ & $\begin{array}{l}0.226 \\
(0.0218)\end{array}$ & $\begin{array}{l}0.233 \\
(0.0226)\end{array}$ & $\begin{array}{l}0.221 \\
(0.0215)\end{array}$ & $\begin{array}{l}0.222 \\
(0.0216)\end{array}$ & $\begin{array}{l}0.226 \\
(0.0089)\end{array}$ \\
\hline $\begin{array}{l}\text { Wire and Wire Products } \\
\text { Manufacturers }\end{array}$ & & $\begin{array}{l}0.203 \\
(0.0204)\end{array}$ & $\begin{array}{l}0.195 \\
(0.0204)\end{array}$ & $\begin{array}{l}0.191 \\
(0.0203)\end{array}$ & $\begin{array}{l}0.189 \\
(0.0206)\end{array}$ & $\begin{array}{l}0.172 \\
(0.0208)\end{array}$ & $\begin{array}{l}0.183 \\
(0.0206)\end{array}$ & $\begin{array}{l}0.189 \\
(0.0084)\end{array}$ \\
\hline Machine Shops & & $\begin{array}{l}0.318 \\
(0.0407)\end{array}$ & $\begin{array}{l}0.291 \\
(0.0353)\end{array}$ & $\begin{array}{l}0.301 \\
(0.0369)\end{array}$ & $\begin{array}{l}0.288 \\
(0.0340)\end{array}$ & $\begin{array}{l}0.307 \\
(0.0376)\end{array}$ & $\begin{array}{l}0.315 \\
(0.0397)\end{array}$ & $\begin{array}{c}0.302 \\
(0.0152)\end{array}$ \\
\hline $\begin{array}{l}\text { Agriculture Implement } \\
\text { Industry }\end{array}$ & & $\begin{array}{l}0.159 \\
(0.0211)\end{array}$ & $\begin{array}{l}0.162 \\
(0.0207)\end{array}$ & $\begin{array}{l}0.183 \\
(0.0222)\end{array}$ & $\begin{array}{l}0.148 \\
(0.0212)\end{array}$ & $\begin{array}{l}0.155 \\
(0.0212)\end{array}$ & $\begin{array}{l}0.135 \\
(0.0229)\end{array}$ & $\begin{array}{l}0.157 \\
(0.0088)\end{array}$ \\
\hline $\begin{array}{l}\text { Misc: Machinery and Equip } \\
\text { ment Manufacturers }\end{array}$ & & $\begin{array}{l}0.193 \\
(0.0201)\end{array}$ & $\begin{array}{l}0.197 \\
(0.0202)\end{array}$ & $\begin{array}{l}0.187 \\
(0.0199)\end{array}$ & $\begin{array}{c}0.178 \\
(0.0197)\end{array}$ & $\begin{array}{l}0.170 \\
(0.0198)\end{array}$ & $\begin{array}{c}0.175 \\
(0.0197)\end{array}$ & $\begin{array}{l}0.183 \\
(0.0081)\end{array}$ \\
\hline $\begin{array}{l}\text { Aircraft and Aircraft } \\
\text { Parts Manufacturer } 8\end{array}$ & & $\begin{array}{l}0.144 \\
(0.0211)\end{array}$ & $\begin{array}{l}0.148 \\
(0.0209)\end{array}$ & $\begin{array}{c}0.151 \\
(0.0206)\end{array}$ & $\begin{array}{l}0.181 \\
(0.0197)\end{array}$ & $\begin{array}{l}0.167 \\
(0.0200)\end{array}$ & $\begin{array}{l}0.158 \\
(0.0206)\end{array}$ & $\begin{array}{c}0.159 \\
(0.0084)\end{array}$ \\
\hline $\begin{array}{c}\text { Motor Vehicle Parts and } \\
\text { Accessories Mnfrs. }\end{array}$ & & $\begin{array}{l}0.171 \\
(0.0228)\end{array}$ & $\begin{array}{l}0.185 \\
(0.0223)\end{array}$ & $\begin{array}{l}0.178 \\
(0.0231)\end{array}$ & $\begin{array}{l}0.178 \\
(0.0231)\end{array}$ & $\begin{array}{l}0.179 \\
(0.0215)\end{array}$ & $\begin{array}{l}0.179 \\
(0.0220)\end{array}$ & $\begin{array}{l}0.178 \\
(0.0092)\end{array}$ \\
\hline Shipbuilding and Repair & $\cdot$ & $\begin{array}{l}0.126 \\
(0.0253)\end{array}$ & $\begin{array}{l}0.129 \\
(0.0258)\end{array}$ & $\begin{array}{l}0.124 \\
(0.0269)\end{array}$ & $\begin{array}{l}0.135 \\
(0.0246)\end{array}$ & $\begin{array}{l}0.129 \\
(0.0258)\end{array}$ & $\begin{array}{l}0.127 \\
(0.0264)\end{array}$ & $\begin{array}{l}0.129 \\
(0.0105)\end{array}$ \\
\hline $\begin{array}{l}\text { Communications Equip- } \\
\text { ment Manufacturers }\end{array}$ & & $\begin{array}{l}0.274 \\
(0.0397)\end{array}$ & $\begin{array}{l}0.288 \\
(0.0405)\end{array}$ & $\begin{array}{l}0.299 \\
(0.0423)\end{array}$ & $\begin{array}{l}0.286 \\
(0.0415)\end{array}$ & $\begin{array}{l}0.268 \\
(0.0384)\end{array}$ & $\begin{array}{c}0.278 \\
(0.0389)\end{array}$ & $\begin{array}{c}0.282 \\
(0.0164)\end{array}$ \\
\hline $\begin{array}{l}\text { Mnfrs. of Electrical } \\
\text { Industrial Equipt. }\end{array}$ & & $\begin{array}{l}0.205 \\
(0.0238)\end{array}$ & $\begin{array}{l}0.197 \\
(0.0250)\end{array}$ & $\begin{array}{c}0.216 \\
(0.0254)\end{array}$ & $\begin{array}{l}0.192 \\
(0.0254)\end{array}$ & $\begin{array}{c}0.183 \\
(0.0244)\end{array}$ & $\begin{array}{c}0.197 \\
(0.0247)\end{array}$ & $\begin{array}{c}0.198 \\
(0.0101)\end{array}$ \\
\hline Petroleum Refineries & & $\begin{array}{l}0.146 \\
(0.0248)\end{array}$ & $\begin{array}{c}0.154 \\
(0.0243)\end{array}$ & $\begin{array}{c}0.151 \\
(0.0250)\end{array}$ & $\begin{array}{l}0.160 \\
(0.0262)\end{array}$ & $\begin{array}{l}0.211 \\
(0.0268)\end{array}$ & $\begin{array}{c}0.226 \\
(0.0289)\end{array}$ & $\begin{array}{c}0.171 \\
(0.0106)\end{array}$ \\
\hline $\begin{array}{l}\text { Mnfrs. of Industrial } \\
\text { Chemicals }\end{array}$ & & $\begin{array}{l}0.161 \\
(0.0212)\end{array}$ & $\begin{array}{l}0.159 \\
(0.0213)\end{array}$ & $\begin{array}{l}0.164 \\
(0.0220)\end{array}$ & $\begin{array}{l}0.167 \\
(0.0232)\end{array}$ & $\begin{array}{c}0.161 \\
(0.0229)\end{array}$ & $\begin{array}{l}0.167 \\
(0.0223)\end{array}$ & $\begin{array}{l}0.163 \\
(0.0090)\end{array}$ \\
\hline Logging Eastern Canada & & $\begin{array}{c}0.190 \\
(0.0241)\end{array}$ & $\begin{array}{c}0.183 \\
(0.0234)\end{array}$ & $\begin{array}{l}0.186 \\
(0.0217)\end{array}$ & & & & $\begin{array}{c}0.186 \\
(0.0133)\end{array}$ \\
\hline Logging British Columbia & & $\begin{array}{c}0.168 \\
(0.0202)\end{array}$ & $\begin{array}{c}0.162 \\
(0.0201)\end{array}$ & $\begin{array}{c}0.156 \\
(0.0222)\end{array}$ & & & & $\begin{array}{c}0.162 \\
(0.0120)\end{array}$ \\
\hline Gold-Quartz Mining & & $\begin{array}{c}0.165 \\
(0.0225)\end{array}$ & $\begin{array}{c}0.168 \\
(0.0204)\end{array}$ & $\begin{array}{c}0.162 \\
(0.0205)\end{array}$ & & & & $\begin{array}{c}0.165 \\
(0.0122)\end{array}$ \\
\hline Iron & & $\begin{array}{c}0.113 \\
(0.0260)\end{array}$ & $\begin{array}{c}0.122 \\
(0.0241)\end{array}$ & $\begin{array}{l}0.116 \\
(0.0241)\end{array}$ & & & & $\begin{array}{c}0.117 \\
(0.0142)\end{array}$ \\
\hline Other Metals & & $\begin{array}{l}0.125 \\
(0.0229)\end{array}$ & $\begin{array}{c}0.131 \\
(0.0230)\end{array}$ & $\begin{array}{c}0.140 \\
(0.0250)\end{array}$ & & & & $\begin{array}{c}0.132= \\
(0.0136)\end{array}$ \\
\hline Coal & & $\begin{array}{c}0.315 \\
(0.0407)\end{array}$ & $\begin{array}{c}0.128 \\
(0.0226)\end{array}$ & $\begin{array}{c}0.137 \\
(0.0214)\end{array}$ & & & $\cdot$ & $\begin{array}{c}0.156= \\
(0.0145)\end{array}$ \\
\hline
\end{tabular}


Table 3 (cont'd)

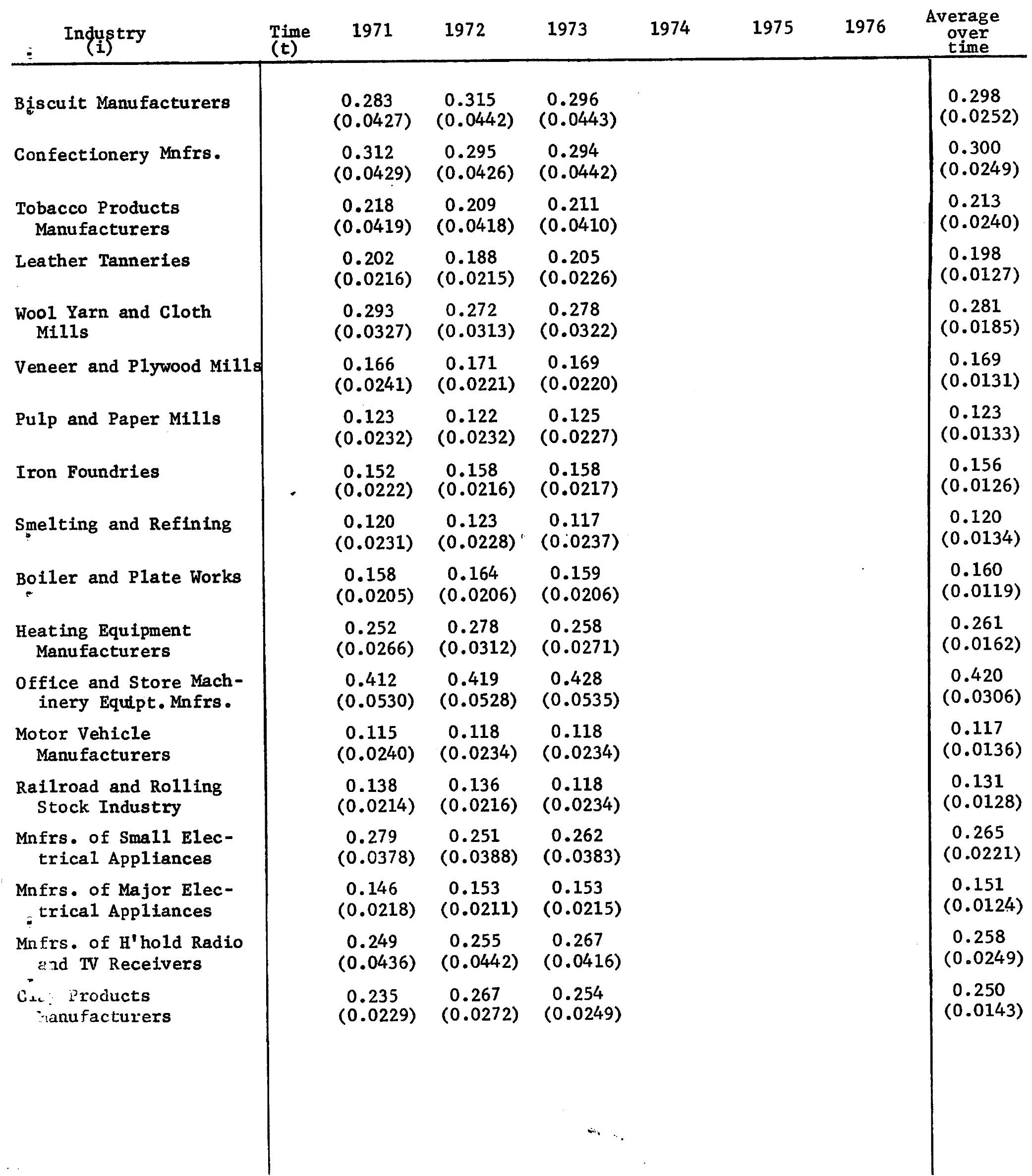


Table 3 (cont'd)

\begin{tabular}{|c|c|c|c|c|c|c|c|c|}
\hline $\begin{array}{l}\text { Industry } \\
\text { (i) }\end{array}$ & $\begin{array}{c}\text { Time } \\
(t)\end{array}$ & 1971 & 1972 & 1973 & 19.74 & 1975 & 1976 & $\begin{array}{c}\text { Average } \\
\text { over } \\
\text { time } \\
\end{array}$ \\
\hline $\begin{array}{l}\text { Glass and Glass Pro- } \\
\text { ducts Manufacturers }\end{array}$ & & $\begin{array}{l}0.185 \\
(0.0231)\end{array}$ & $\begin{array}{l}0.185 \\
(0.0247)\end{array}$ & $\begin{array}{l}0.169 \\
(0.0247)\end{array}$ & & & & $\begin{array}{c}0 \\
0.180 \\
(0.0139)\end{array}$ \\
\hline $\begin{array}{l}\text { Mnfrs. of Pharmaceut- } \\
\text { icals and Medicines }\end{array}$ & & $\begin{array}{l}0.457 \\
(0.0621)\end{array}$ & $\begin{array}{l}0.435 \\
(0.0584)\end{array}$ & $\begin{array}{l}0.430 \\
(0.0575)\end{array}$ & & & & $\begin{array}{l}0.440 \\
(0.0342)\end{array}$ \\
\hline $\begin{array}{l}\text { Paint and Varnish } \\
\text { Manufacturers }\end{array}$ & & $\begin{array}{c}0.305 \\
(0.0374)\end{array}$ & $\begin{array}{l}0.279 \\
(0.0333)\end{array}$ & $\begin{array}{l}0.279 \\
(0.0332)\end{array}$ & & & & $\begin{array}{l}0.286 \\
(0.0199)\end{array}$ \\
\hline \multirow[t]{2}{*}{$\begin{array}{l}\text { Industry } \\
\text { Average }\end{array}$} & & $\begin{array}{c}0.194 \\
(0.0074)\end{array}$ & $\begin{array}{c}0.193 \\
(0.0073)\end{array}$ & $\begin{array}{l}0.193 \\
(0.0074)\end{array}$ & $\begin{array}{l}0.204 \\
(0.0139)\end{array}$ & $\begin{array}{l}0.201 \\
(0.0137)\end{array}$ & $\begin{array}{c}0.201 \\
(0.0138)\end{array}$ & $\begin{array}{l}0.196 \\
(0.0016)\end{array}$ \\
\hline & & & & & & & & $\begin{array}{l}\text { Grand } \\
\text { Average }\end{array}$ \\
\hline
\end{tabular}

